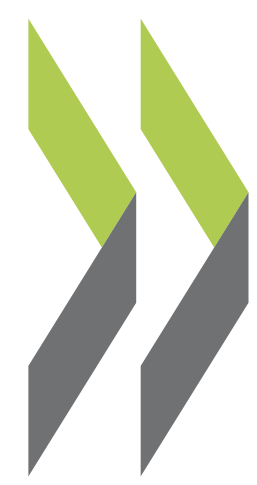

OECD Economics Department Working Papers No. 828

Minimising Risks from Imbalances in European Banking

\section{Sebastian Barnes,}

Philip R. Lane,

Artur Radziwill 
Organisation de Coopération et de Développement Économiques

Organisation for Economic Co-operation and Development

09-Dec-2010

ECONOMICS DEPARTMENT

English - Or. English

MINIMISING RISKS FROM IMBALANCES IN EUROPEAN BANKING

ECONOMICS DEPARTMENT WORKING PAPER No. 828

By Sebastian Barnes, Philip R. Lane and Artur Radziwill

All Economics Department Working Papers are available through OECD's internet web site at www.oecd.org/Working_Papers

JT03294216

Document complet disponible sur OLIS dans son format d'origine

Complete document available on OLIS in its original format 


\section{ABSTRACT/RÉSUMÉ \\ Minimising risks from imbalances in European banking}

The euro area financial system took excessive risks during the global credit boom, which in some countries led to an unsustainable increase in credit, higher asset prices and housing booms. This process helped to fuel large imbalances within the euro area. Banks played a key role in channelling funds from economies with large surpluses to deficit countries, leading in some cases to the accumulation of considerable risks for borrowers and lenders.

Weaknesses in the regulatory and supervisory architecture contributed to these problems in the euro area, as in other OECD economies. Gaps in microprudential regulation created an environment prone to excessive risk-taking: capital buffers were too small; the quality of capital was inadequate; banks' models underestimated risks; and risks were shifted off-balance sheet and beyond supervisory oversight. Liquidity risks were not adequately monitored. Systemic risks were allowed to build up as the authorities largely failed to counter the credit cycle. Some large systemic banks contributed to growing imbalances and vulnerability. The decentralised European supervisory architecture was not sufficiently effective in supervising large cross-border institutions. When the financial crisis hit, the co-ordination of cross-border rescues proved problematic and complicated efficient resolution.

Stronger regulations are needed to improve financial stability. Effective microprudential regulation is the first line of defence. This should be upgraded by implementing the Basel III capital accord, as has been announced by the EU authorities, and a range of related measures. Some consideration should be given to an accelerated phasing-in. Macroprudential regulation should be significantly developed to mitigate pro-cyclicality and reduce systemic risks posed by large cross-border banks. The creation of the European Systemic Risk Board is welcome. To improve crossborder supervision, the European Banking Authority should have sufficient powers and resources to ensure that a system based on national supervision leads to coherent regulation and effective supervision. In addition, a crossborder crisis-management framework for Europe is needed. Overall, significant steps have already been taken by the EU authorities to address these issues and further reforms are under way.

This working paper relates to the 2010 OECD Economic Survey of the Euro area. (www.oecd.org/eco/surveys/EuroArea).

JEL classification: G01; G15; G21; G28

Keywords: euro area; banking system; cross-border capital flows; microprudential regulation; systemic risk; financial stability

\section{Minimiser les risques de déséquilibre au sein du système bancaire européen}

Durant la phase d'explosion du crédit à l'échelle mondiale, le système financier de la zone euro a pris des risques excessifs qui ont abouti, dans quelques pays, à une augmentation insoutenable du crédit et à une flambée des prix des actifs et de l'immobilier. Ce processus a contribué au creusement d'importants déséquilibres au sein de la zone euro. Les banques ont joué un rôle majeur dans la transmission des ressources financières des économies affichant des excédents importants vers les pays déficitaires, ce qui a conduit, dans certains cas, à l'accumulation de risques considérables pour les emprunteurs comme pour les prêteurs.

Les lacunes du dispositif de réglementation et de surveillance ont contribué à ces problèmes dans la zone euro, comme dans les autres économies de 1'OCDE. Les failles de la réglementation microprudentielle ont favorisé la propension à prendre des risques excessifs : les volants de fonds propres des banques étaient trop faibles, la qualité des capitaux n'était pas adaptée, les modèles utilisés par les banques sous-estimaient les risques et ces risques étaient sortis des bilans et échappaient ainsi à la surveillance des autorités de contrôle. De plus, il n'y a pas eu de suivi convenable des risques de liquidité. Comme les autorités n'ont guère su s'opposer à l'expansion du crédit, des risques systémiques ont pu s'accumuler. Certaines grandes banques d'importance systémique ont contribué à l'aggravation des déséquilibres et de la vulnérabilité du système. Le dispositif européen de surveillance décentralisé n'était pas assez efficace pour contrôler les grandes institutions financières transnationales. Lorsque la crise financière a éclaté, la coordination des différents plans de sauvetage nationaux s'est avérée problématique et a contrarié le règlement efficient des faillites des établissements.

Il convient de renforcer la réglementation de façon à améliorer la stabilité financière. La première ligne de défense réside dans une réglementation microprudentielle efficace. Cette réglementation doit être améliorée en appliquant l'Accord de Bâle III sur les fonds propres, comme l'ont annoncé les autorités de l'UE, ainsi qu'une série de mesures connexes. Il conviendrait d'envisager une accélération de leur mise en œuvre. La réglementation macroprudentielle doit être nettement développée de façon à atténuer le caractère procyclique du dispositif et à 
réduire les risques systémiques que présentent les grands établissements transnationaux. La création du Comité européen du risque systémique est bienvenue. Pour améliorer la surveillance transnationale, l'Autorité bancaire européenne doit être dotée de prérogatives et de ressources suffisantes pour qu'un système fondé sur une surveillance exercée à l'échelle nationale donne naissance à une réglementation cohérente et un contrôle efficace. En outre, il convient de mettre en place un dispositif transfrontalier de gestion des crises à l'échelle de l'Europe. En résumé, les autorités européennes ont déjà pris des mesures substantielles pour s'attaquer à ces questions, et d'autres réformes sont en cours.

Ce document de travail porte sur l'Étude économique du Zone euro.

(www.oecd.org/eco/etudes/zoneeuro).

Classification JEL : G01 ; G15 ; G21 ; G28

Mots clés : zone euro ; système bancaire ; flux de capitaux internationaux ; réglementation microprudentielle ; risque systémique ; stabilité financière

Copyright OECD 2010

Application for permission to reproduce or translate all, or part of, this material should be made to: Head of Publications Service, OECD, 2 rue André-Pascal, 75775 Paris Cedex 16, France 


\section{TABLE OF CONTENTS}

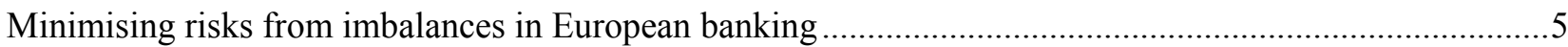

The bank lending cycle was unsustainable and contributed to imbalances ..............................................5

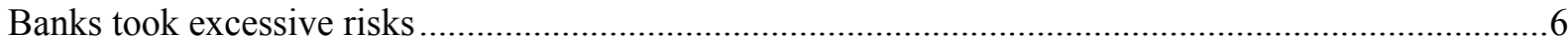

Cross-border banking flows fuelled imbalances and increased risk ................................................. 8

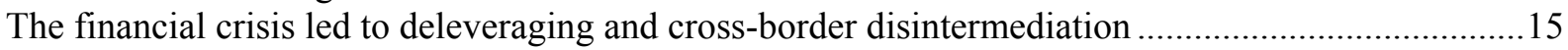

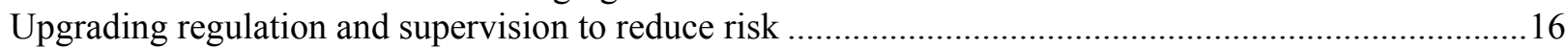

More robust microprudential regulation should provide the first line of defence.................................16

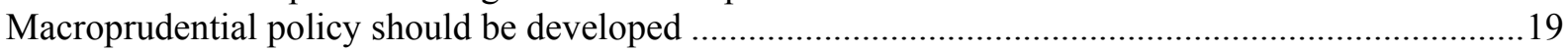

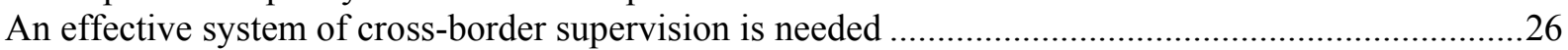

An integrated crisis-management framework would reduce moral hazard ..........................................30

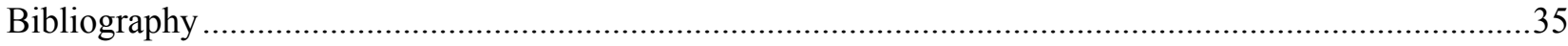

\section{Tables}

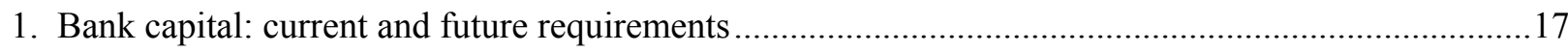

2. Pro-forma leverage ratios under GAAP and IFRS....................................................................18

\section{Figures}

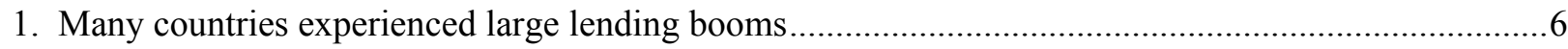

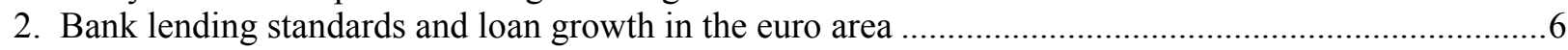

3. Loan loss provisions and economic growth in the euro area ...........................................................

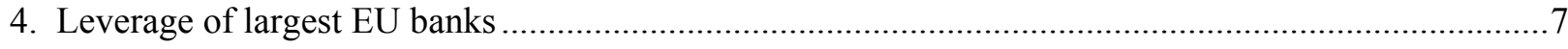

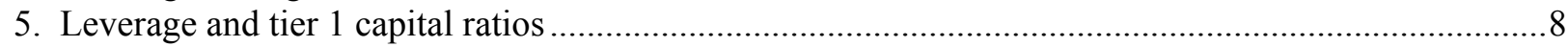

6. Banking flows played a major role in accumulation of imbalances ..................................................

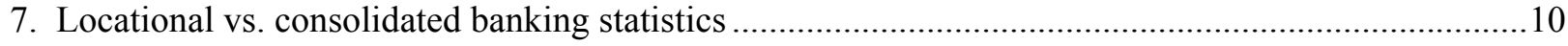

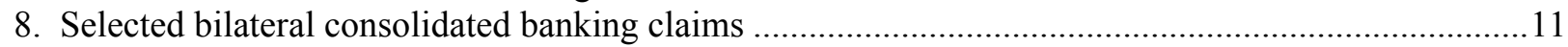

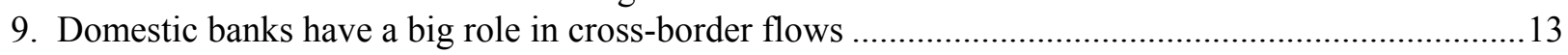

10. Cross-border provision of financial services in the euro area.......................................................13

11. Assets of branches and subsidiaries of euro area credit institutions .............................................15

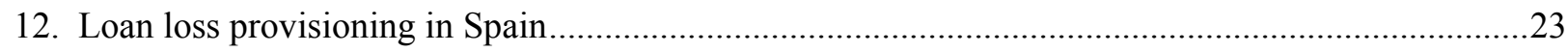

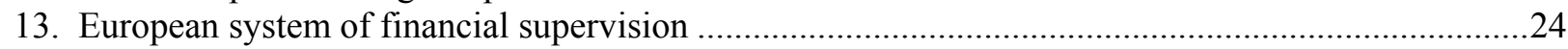

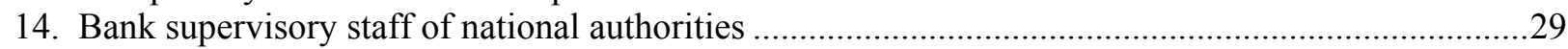

\section{Boxes}

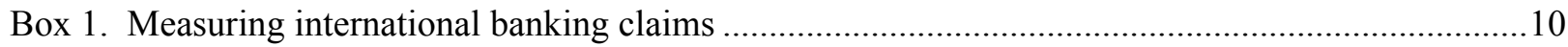

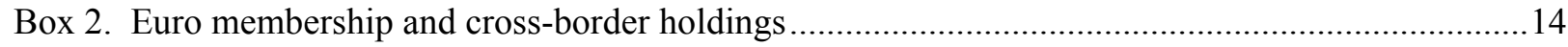

Box 3. Comparison of leverage in the United States and the euro area ................................................18

Box 4. The macroeconomic impact of the new Basel capital requirements ..........................................19

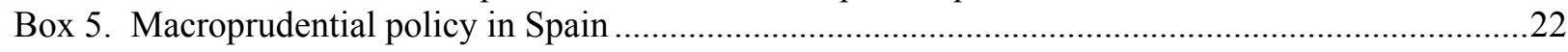

Box 6. The supervisory architecture prior to the crisis and the reforms ..............................................26

Box 7. Major financial firms live globally but die locally: the case of Fortis .........................................

Box 8. The Nordic-Baltic Cross-Border Stability Group (NBCBSG) ...................................................32 
ECO/WKP(2010)84

\title{
Minimising risks from imbalances in European banking
}

\author{
By Sebastian Barnes, Philip R. Lane and Artur Radziwill ${ }^{1}$
}

Excessive risk-taking in the euro area during the global credit cycle contributed to the financial crisis, the severity of the economic downturn, and considerable fiscal costs. While the euro area in aggregate avoided some of the worst excesses, this paper argues that there were serious problems in a number of countries, particularly those that had run large external imbalances. The first section shows how banks increased risk-taking, and how cross-border bank flows were a key part of the build-up of macroeconomic and financial imbalances, as differences in borrowing and saving behaviour across countries led to excess funds from some countries partly being recycled elsewhere in the euro area. The second section sets out the main policy priorities, both to avoid excessive risk-taking overall and to prevent unsustainable financial imbalances in euro area countries. These include stronger microprudential regulations, developing macroprudential policy, improving cross-border supervision and setting up a cross-border crisismanagement framework.

\section{The bank lending cycle was unsustainable and contributed to imbalances}

The strong banking cycle during the recent upswing in euro area countries, as in other OECD economies, led to unsustainable borrowing and left the financial system vulnerable. Loan growth was well in excess of GDP growth. When doubts about global credit quality appeared in 2007, credit began to slow, before contracting as banks made significant losses on their earlier activities and borrower demand deteriorated as the economy slowed. Within the euro area, economic imbalances across countries were associated with large variations in credit expansion (Barnes, forthcoming). The pace of borrowing in several deficit countries was extremely high due to low real interest rates, financial deepening, optimistic growth expectations and financial accelerator mechanisms. Key loan aggregates doubled or tripled in some cases between 2002 and 2007 (Figure 1). By contrast, credit growth was sluggish in several surplus countries and lending was largely stagnant in Germany. Credit expansion in deficit countries financed excessive saving-investment gaps and fuelled consumption, housing and asset price booms. It also led to the misallocation of capital, especially towards the housing and non-tradable sectors. These developments added to macroeconomic risks: the severity of the 2008-09 downturn across countries was associated with the speed of credit expansion during the 2004-07 pre-crisis period (Lane and Milesi-Ferretti, 2010).

1. Sebastian Barnes and Artur Radziwill are economists in the Economics Department of the OECD. Philip R. Lane is Professor of International Macroeconomics at Trinity College Dublin. This paper is based largely on work originally prepared for the Economic Survey of the Euro Area published on 13 December 2010 under the authority of the Economics and Development Review Committee (EDRC). The authors would like to thank Piritta Sorsa, Andrew Dean and colleagues in the Economics Directorate of the OECD for comments on earlier drafts, but retain full responsibility for any errors or omissions. Thanks to Patrick Slovik and Daniele Siena for useful inputs. Thanks to Isabelle Duong for excellent technical assistance and to Deirdre Claassen for technical preparation. 
Figure 1. Many countries experienced large lending booms Level in 2007

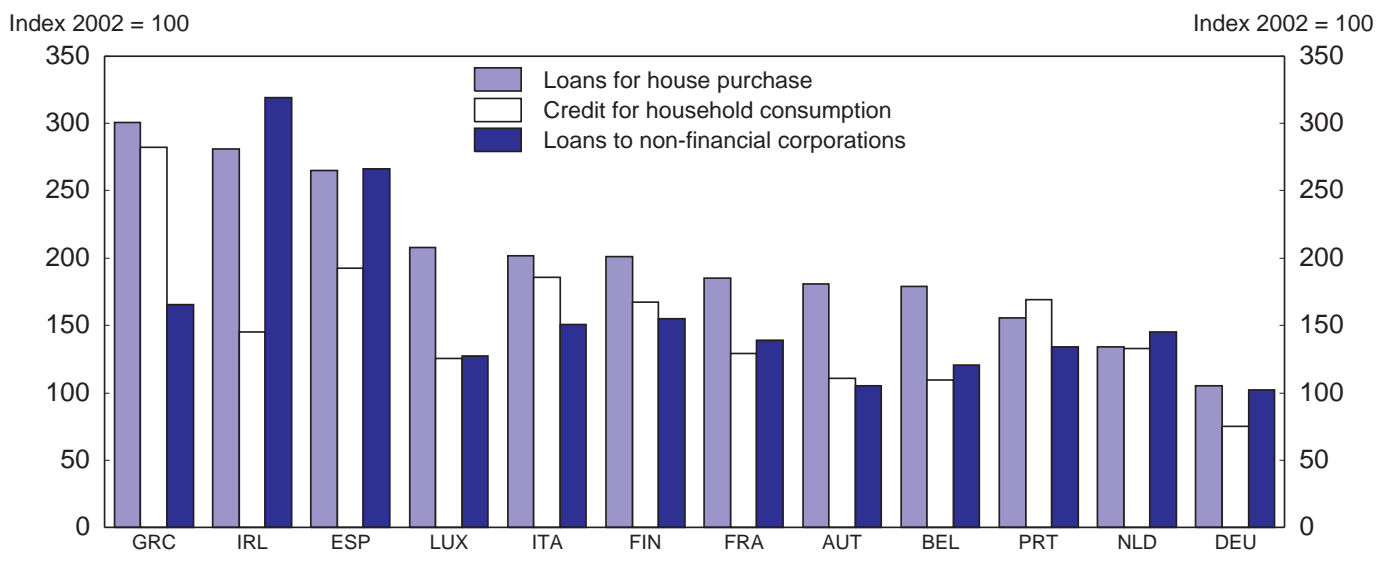

Source: ECB.

\section{Banks took excessive risks}

The expansion of bank credit was facilitated by an easing of lending standards, as reported by the ECB Bank Lending Survey (Figure 2). This credit easing led to stronger bank lending and higher GDP growth (De Bondt et al., 2010). Credit growth in the pre-crisis period was reinforced by the balance sheet channel, as household and corporate assets swelled, thereby increasing the value of collateral, and through the bank lending channel, as banks had plentiful profits to fund additional capital and lending (Hempell and Kok Sørensen, 2009). These developments were, among other things, influenced by low interest rates across the maturity spectrum, increased securitisation and gaps in bank supervision (Maddaloni and Peydro, 2010). Similar effects occurred elsewhere, notably in the United States (Bayoumi and Melander, 2008). This mechanism was particularly strong in euro area deficit countries, given the structure of financial markets and the tendency for these feedback mechanisms to operate locally.

Figure 2. Bank lending standards and loan growth in the euro area

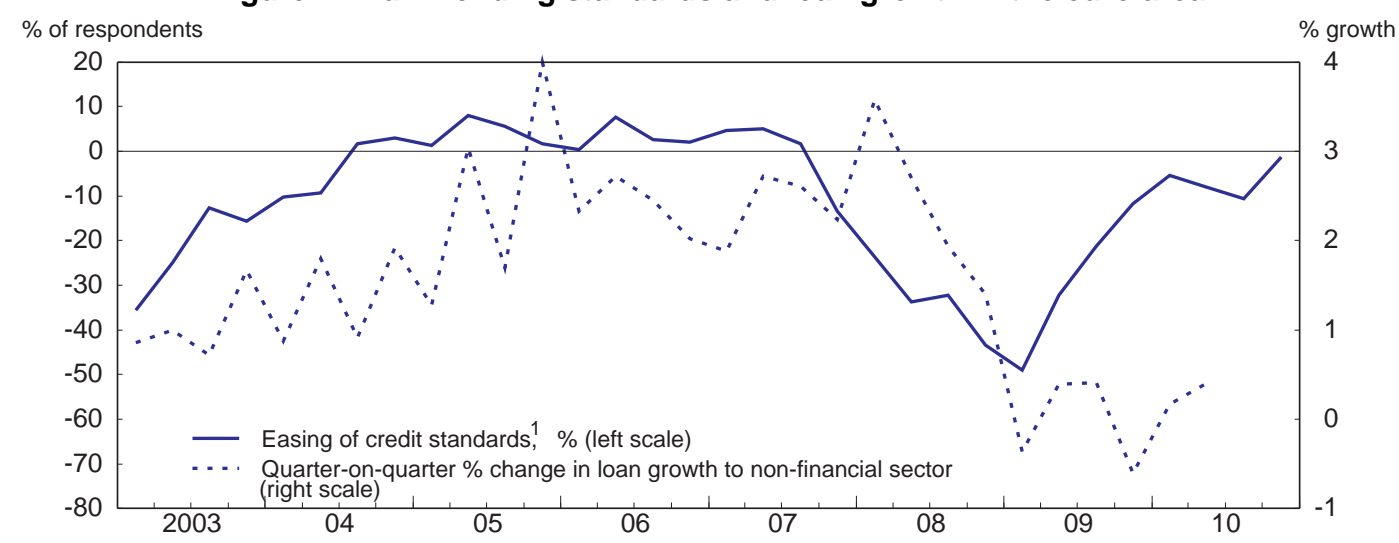

1. Net percentage of respondents reporting easing of credit standards: average of credit to enterprises, home purchases and consumer credit.

Source: ECB, Bank Lending Survey.

The risks associated with growing lending were not adequately reflected in the size of bank provisions, which declined to historically low levels while activity and credit were at cyclical highs (Figure 3). Provisions during the upswing fell by more, relative to aggregate output dynamics, than in any other recent credit cycle, and increased abruptly in the wake of the crisis. This is unsurprising given the 
point-in-time approach to provisioning, and limits on making general provisions that were the prevailing norm due to international accounting standards.

Figure 3. Loan loss provisions and economic growth in the euro area

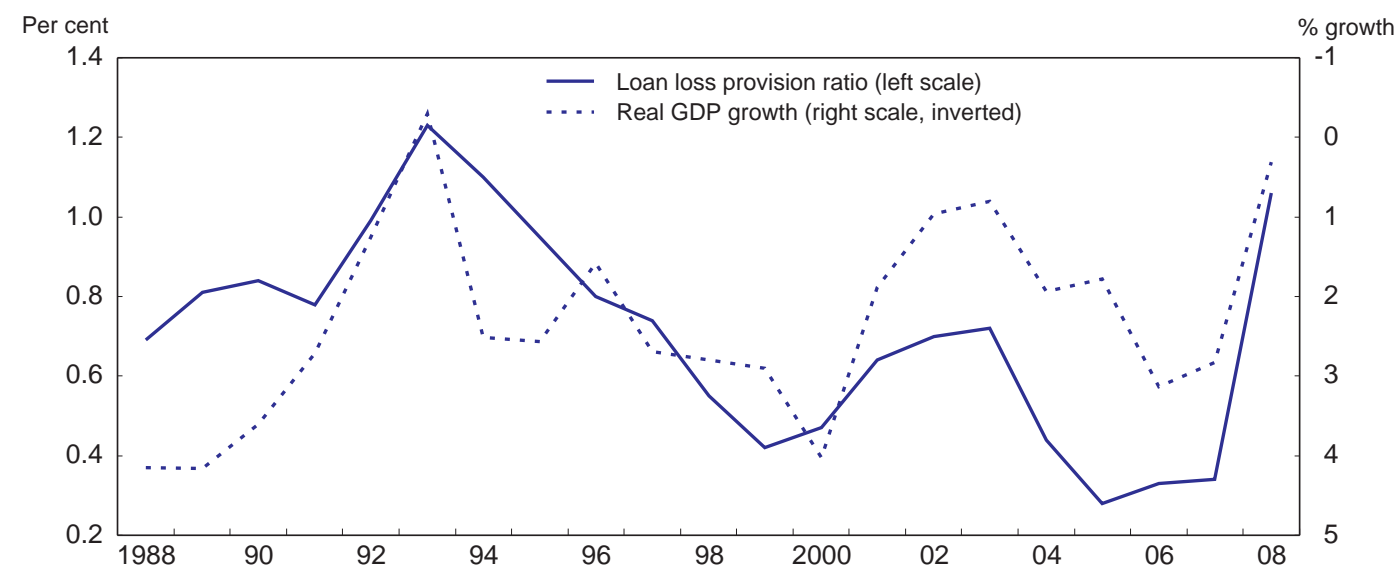

Source: OECD, Bank Profitability Statistics Database; OECD Economic Outlook Database and OECD calculations.

Loan growth and risk-taking were facilitated by increases in bank leverage, as in other OECD economies. Assets grew faster than capital over the pre-crisis period from 2002 to 2006. While the increase in the aggregate leverage of the euro area banking system was small, it was substantial for the largest and most systemically relevant banks. The leverage ratio, defined as the ratio of total assets to tier 1 capital, for the major banks increased during the pre-crisis period by around one-third (Figure 4). At the same time, the tier 1 risk-weighted ratio of the largest euro area banks only weakened modestly over this period. This suggests an increasing discrepancy between total and risk-weighted assets, which might suggest that riskbased aggregates did not adequately reflect changes in total risk exposures. In addition, some risk exposures were put off balance sheet so that bank balance sheets failed fully to capture increasing risktaking.

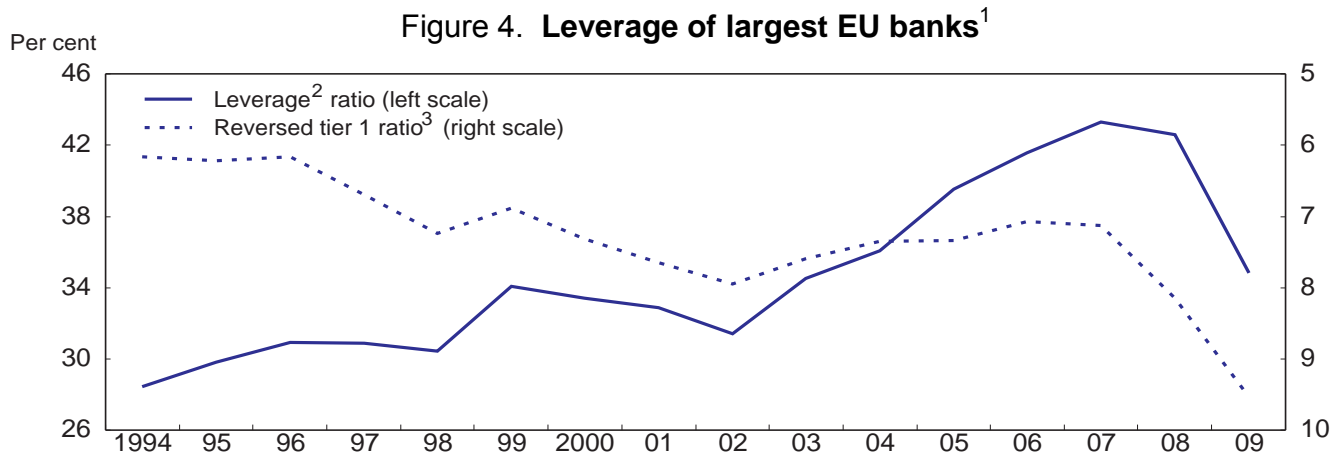

1. The 10 largest banks in the euro-area are selected based on their total assets in 2006, which is the last pre-crisis year, and include BNP Paribas, Crédit Agricole, Deutsche Bank, ABN AMRO, Société Générale, ING Bank, Banco Santander, UniCredit, Fortis and Commerzbank.

2. Ratio of total assets to tier 1 capital.

3. Ratio of risk-weighted assets to tier 1 capital.

Source: The Banker Database and OECD calculations.

Across euro area countries, regulatory tier 1 capital ratios were relatively similar (Figure 5). However, leverage ratios generally remained much lower in deficit countries (except Ireland), while leverage was higher in a number of surplus countries with large and sophisticated financial institutions. These discrepancies might also reflect differences across countries in the supervisory approach, as shown for 
example by the treatment of asset-backed commercial paper conduits in different countries (Acharya and Schnabl, 2010). In the early 2000s, Spain required a full capital charge against assets in conduits, which meant that there was no difference between capital requirements for assets held on or off balance sheet. As a result, Spanish banks avoided substantial exposure to these conduits and off-balance sheet items accounted only for about 6-7\% of total securitisation in Spain (Fernandez de Lis and Herrero, 2008). By contrast, the German regional banks (Landesbanken) benefited from grandfathered state guarantees, which reduced their cost of capital. Supervisors allowed these banks to invest in conduits, which were put off balance sheet for regulatory purposes even though they were included in financial reporting. The Landesbanken invested heavily in these conduits, financed through short-term debt. As a result, they were exposed to risky assets originated in overheating overseas markets and incurred large losses when the crisis began.

Figure 5. Leverage and tier 1 capital ratios In 2006

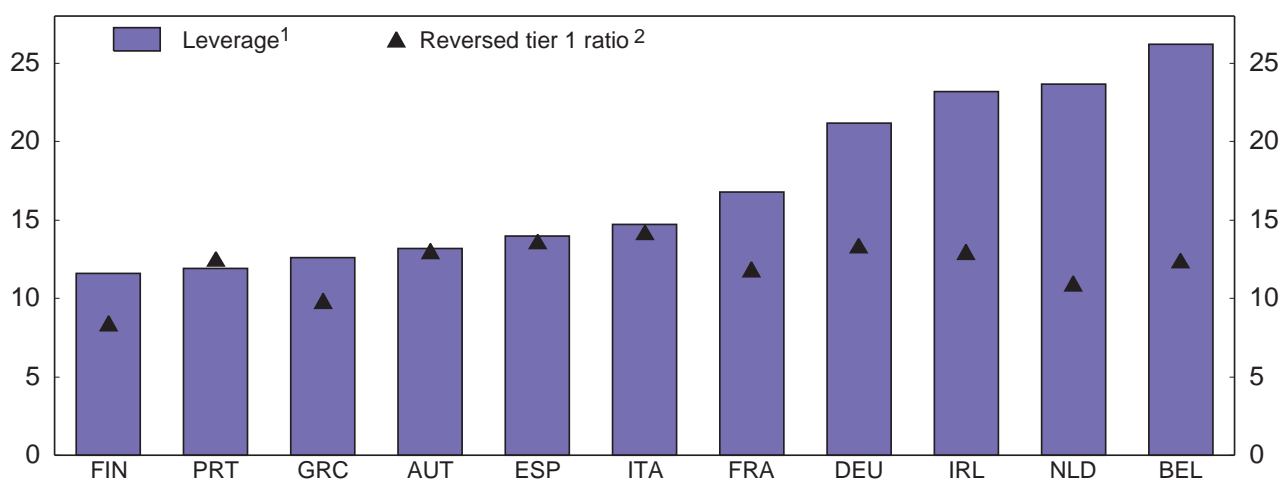

1. Ratio of total assets to tier 1 capital.

2. Ratio of risk-weighted assets to tier 1 capital; 2005 data for Austria and Germany.

Source: ECB, EU Banking Sector Stability, November 2006 and November 2007.

\section{Cross-border banking flows fuelled imbalances and increased risk}

The accumulation of macroeconomic imbalances within the euro area was accompanied by large cross-border banking flows. In several countries, the net external position of domestic residents towards foreign banks, measured on a locational basis, rapidly deteriorated (Box 1). This illustrates the close link between bank flows and changes in the overall dependence of domestic residents on external financing (Figure 6, first panel). Conversely, the domestic banking sector has a substantial share of aggregate foreign assets and liabilities (Figure 6, second panel). This share increased rapidly in several deficit countries during the pre-crisis credit boom, notably in Greece where it rose from 17\% in 2002 to 31\% in 2007. 
Figure 6. Banking flows played a major role in accumulation of imbalances
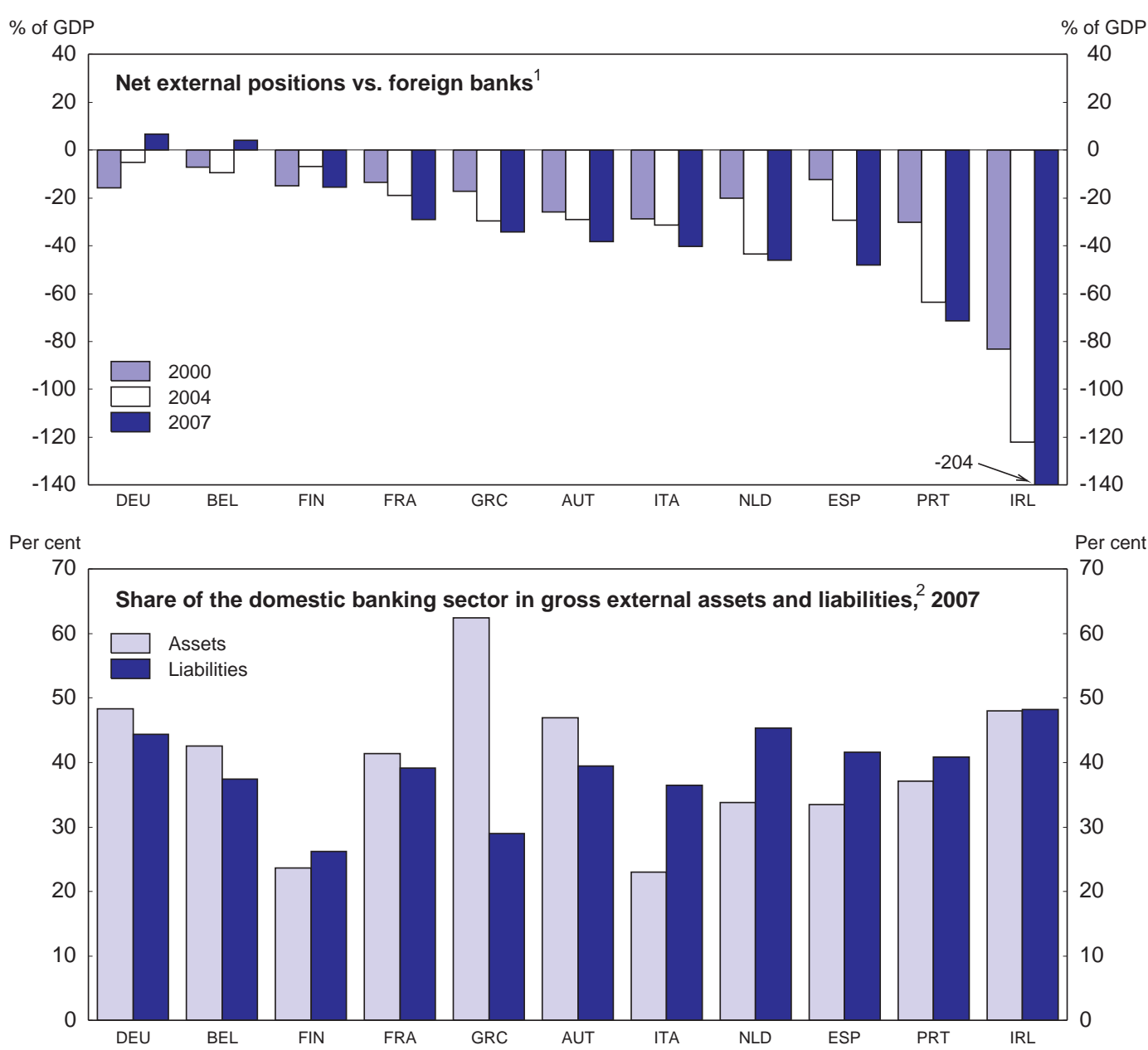

1. Calculated based on locational basis.

2. Excluding foreign direct investment positions maintained by banks.

Source: BIS, Locational Banking Statistics and IMF, Balance of Payments Statistics. 


\section{Box 1. Measuring international banking claims}

The BIS locational banking statistics are based on the residency of the reporting bank. They include positions vis-à-vis banks' foreign offices and complement monetary and credit aggregates, which makes the approach consistent with balance of payments statistics and the system of national accounts (McGuire and Woolridge, 2005). However, resident banks include domestic operations of subsidiaries of foreign-owned banks but exclude foreign subsidiaries of domestic banks.

By contrast, the BIS consolidated banking statistics are based on the nationality of the reporting bank, based on the location of a bank's head office. They exclude intragroup positions to capture solely exposures to unaffiliated counterparties. These statistics allow for a better monitoring of banks' risk exposures. Consolidated statistics are particularly useful in understanding countries' bilateral claims, when those are intermediated through financial centres located in third countries.

The difference between the two approaches is illustrated in Figure 7. Locational statistics report international banking claims for country $X$ as the aggregate claims of banks $B 1$ and $B 3$ on residents outside country $X$. Consolidated statistics will report these claims aggregated for banks B1 and B2. For a financial centre, bank B2 located in country $Y$ might play an important role in channelling credit from country $X$ to country $Z$. In such a situation, the actual exposure of country $X$ to borrowers in country $Z$ would be reflected in the consolidated but not in the locational statistics.

\section{Figure 7. Locational vs. consolidated banking statistics}

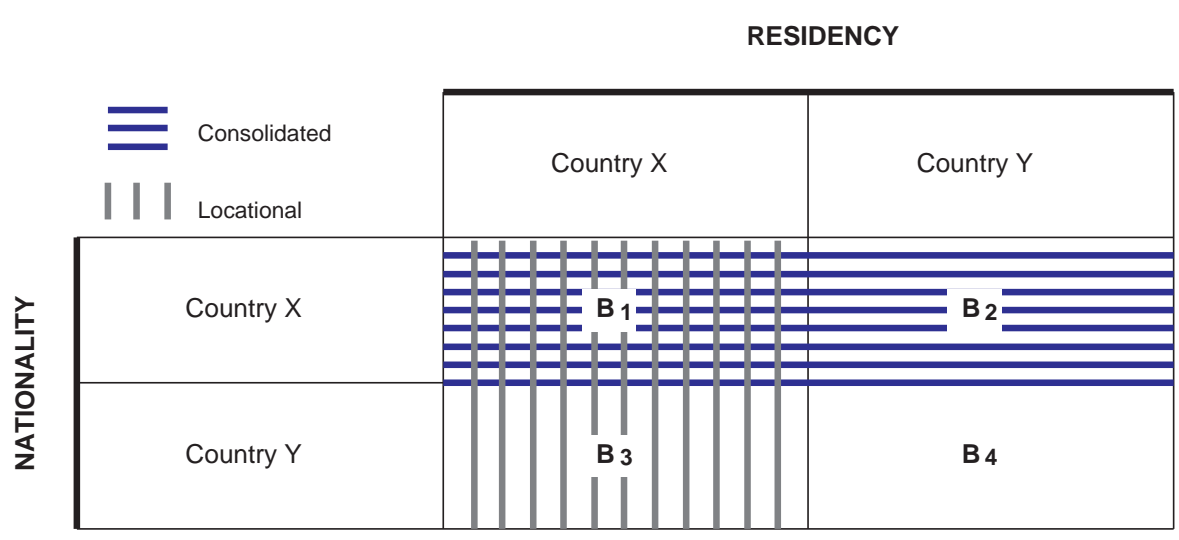

Source: Bank for International Settlements.

Net flows from large surplus countries to those with current account deficits and booming credit markets were particularly important (Figure 8). The extent of the mismatch between flows in opposite directions was large by historical standards and appears to have intensified as the credit cycle took off after the early 2000s. The consolidated claims on some of the large deficit countries were sizeable relative to their GDP, while these flows remained small from the perspective of surplus countries: for example, claims of German banks on Greece increased to just around 1.3\% of German GDP prior to the crisis, but this represented $13.5 \%$ of Greek GDP. This illustrates the sensitivity of small financially open economies in a single financial market to conditions in other countries, particularly in large economies with big pools of saving and bank credit to allocate overseas. Even a relatively modest increase in the external holdings of a large country can dramatically increase the size of funds available to a small deficit economy. Relatively large and unbalanced bilateral consolidated claims accumulated between Portugal and Spain, but imbalances between other deficit countries remained modest. Bilateral claims between France and Germany remained broadly balanced. 
Figure 8. Selected bilateral consolidated banking claims

Claims of country $X$ on country $Y$ as a share of GDP of both countries in 2007
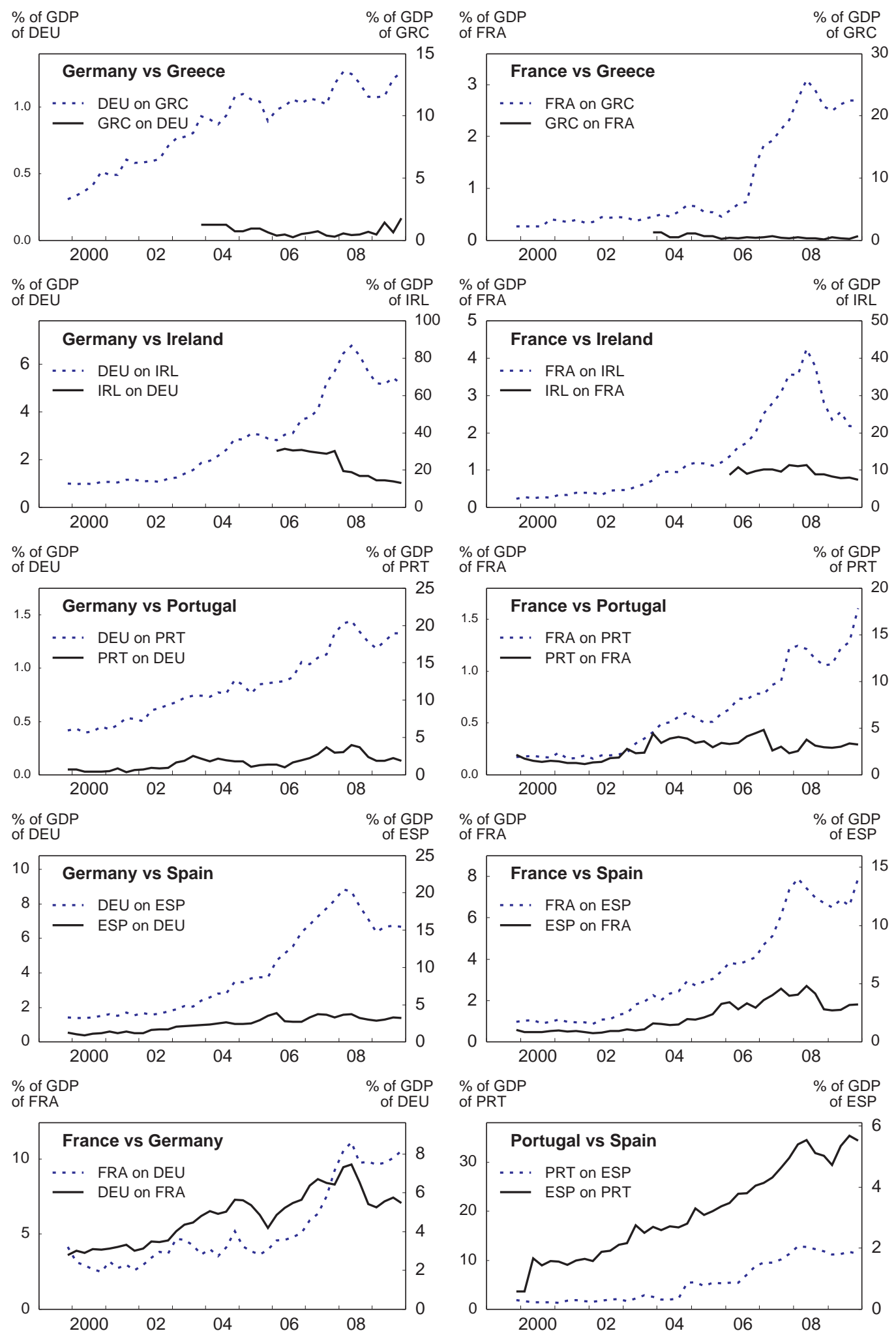

Source: BIS, Consolidated Banking Statistics Database and OECD, OECD Economic Outlook Database. 


\section{ECO/WKP(2010)84}

This rapid increase in cross-border banking claims tested banks' capacity to channel funds to most productive uses (Portes, 2009). Banks in surplus countries were pushed particularly strongly to identify profitable investments abroad, as opportunities for domestic lending were limited due to weak aggregate demand and structural barriers to the development of some domestically focussed economic activities. Direct cross-border lending to the non-financial sector remained limited, as banks primarily lent to other banks or invested in financial instruments of increasing complexity. The riskiness of these investments was underestimated not only by banks, but also by banking supervisors. This led to large losses during the financial crisis on some cross-border investments. Banks in deficit countries increased mainly their domestic risk-taking but also acted as a conduit for foreign financing. The limited supply of growthenhancing projects and distorted credit demand due to low real interest rates led banks to finance housing and consumption booms. These booms became self-perpetuating, due to financial accelerators and unanchored asset price expectations. In some countries, high exposure to domestic sovereign risks and excessive dependence on cross-border wholesale short-term financing added to the problem. In Ireland, a deficit country that developed as a financial centre, banks were not only exposed to unsustainable domestic lending, but also to housing markets abroad, and became highly leveraged. Growing systemic risk was masked by strong profits and capital positions. Macroprudential policies were effectively applied only in limited cases, notably in Spain through dynamic provisioning. These policies did not succeed in preventing the accumulation of excessive risks in the banking system with regard to certain assets (such as real estate in Spain) nor macroeconomic instability, but they did contribute to the resilience of the banking system during the downturn.

The key role of domestic banks in intermediating funds from foreign banks to domestic borrowers reflects incomplete financial integration and diversification in the EU retail banking market. Domestic banks generally dominate overall national exposures to, and claims on, foreign banks (Figure 9). This pattern is consistent with deeper financial integration in European wholesale and securities-related banking than in retail banking (Figure 10). Cross-border deposits of the non-financial sector in most countries are small, accounting for just $6 \%$ of the total on average. For countries where deposits are high relative to loans, banks rather than the non-financial sector allocated these funds through foreign lending. Similarly, ECB data show that the extent of cross-border lending to non-bank entities is only $5 \%$ of total loans to nonbanks on average, up from 3\% in the early years of EMU. The retail banking market remains fragmented, with non-trivial differences in lending and deposit rates for households and firms across the euro area. This fragmentation is not too surprising in view of the importance of local information or language in assessing small-business and consumer loans, and differences in national legal systems in the enforcement of repayment and foreclosure procedures. However, this structure creates inherent dangers for the European financial system: ultimate borrowers and lenders may be far removed from each other in terms of geography and their local markets. While banks with a local presence might be well informed about the nature of local risks, this may no more than shift the asymmetric information problem to the assessment of riskiness of the local bank and its activities by foreign lenders. At the same time, it creates a strong need to supervise cross-border activities effectively to avoid, for example, excessive maturity transformation due to the channelling of cross-border flows through short-term interbank markets. 
Figure 9. Domestic banks have a big role in cross-border flows Share of domestic banks in total gross positions vs. foreign banks, 2007

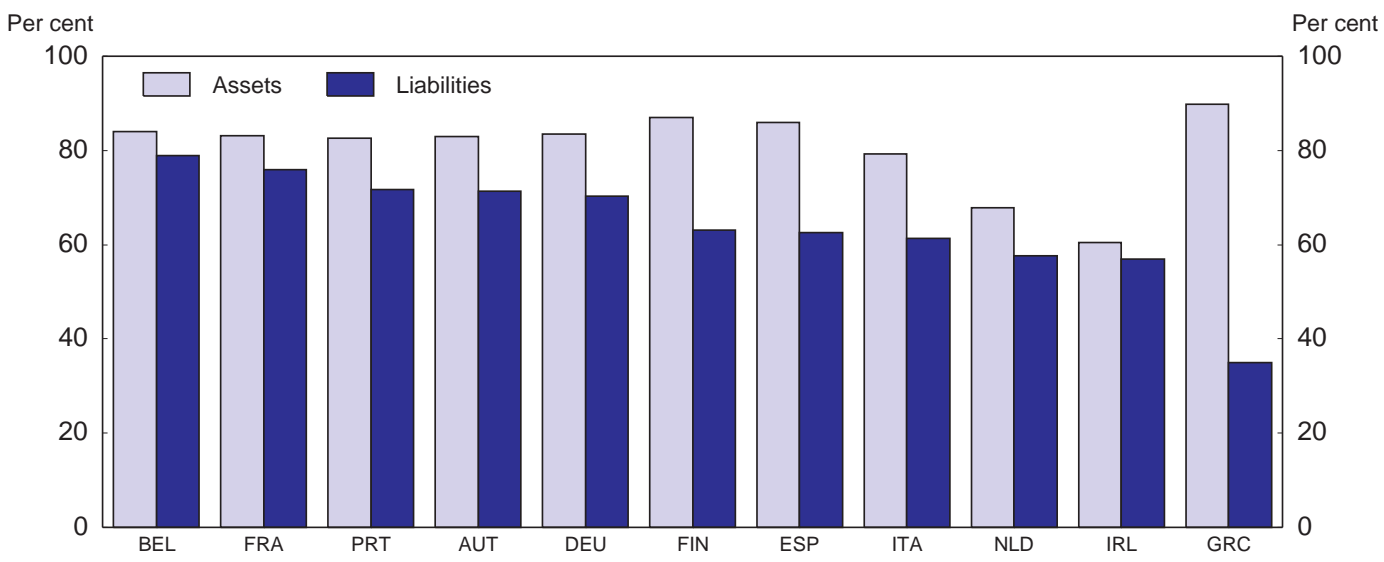

Source: BIS, Locational Banking Statistics and IMF, Balance of Payments Statistics

Figure 10. Cross-border provision of financial services in the euro area ${ }^{1}$
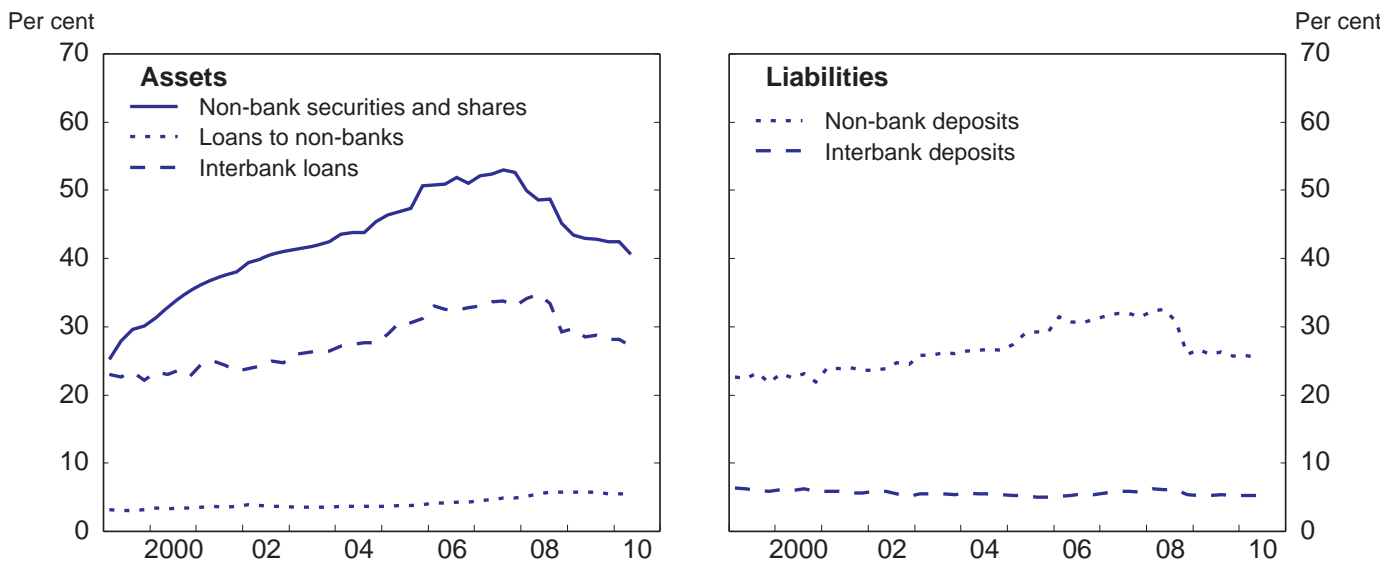

1. Cross-border activity as a percentage of the total provision of financial services in the euro area. Source: ECB (2010), Financial integration in Europe, April.

While financial integration has proceeded slowly in some respects, cross-border interbank flows have developed extremely rapidly through loans, deposits and purchases of securities especially in euro area countries (Box 2). A key development has been the growing role of non-deposit liabilities in recent years. Bond finance and securitised instruments have become more important as sources of funding, transforming balance sheets of banks. Cross-border interbank loans between euro area banks increased from $22 \%$ of total interbank loans in 2000 to $34 \%$ in 2008 , while the holdings of securities issued in other euro area countries grew from a quarter to half of the total. The increasing importance of cross-border interbank flows in financing domestic banks, with highly concentrated exposures to the local retail markets, made them highly vulnerable to shifts in wholesale funding markets. From 2003 to 2007, money market funding increased from $12 \%$ to $16 \%$ of total liabilities, while short-term interbank funding rose from $0.1 \%$ to $2.9 \%$. 


\section{Box 2. Euro membership and cross-border holdings}

Increased financial integration has been a major feature of the world economy over the past decades. However, the monetary union, along with EU regulatory harmonisation, has contributed to this process and has raised the degree of integration among euro area countries.

A study of bilateral cross-border bank holdings for a sample of 20 advanced economies over a 30 -year horizon shows that common membership of the Economic and Monetary Union (EMU) raises bilateral bank holdings by $40 \%$ relative to a pair of non-members (Kalemli-Ozcan et al., 2010). Moreover, the analysis shows that this positive effect is mostly attributable to the elimination of currency risk among members of the euro area. In addition, regulatory harmonisation at the EU level has further boosted bilateral bank holdings.

In earlier studies, Blank and Buch (2007) estimate a gravity model for cross-border bank assets and liabilities, and find a significantly positive euro effect on the distribution of bank assets, but a weaker one for bank liabilities. Coeurdacier and Martin (2007) also find a positive euro effect on bilateral bank lending among the member countries, in addition to increased lending by banks from outside the euro area to entities in the member countries.

The relative increase in bilateral bank claims involving euro area members can be attributed to three different channels (Spiegel, 2009). Firstly, a "borrower" effect, by which EMU membership increases creditworthiness, raising borrowing from all sources. Secondly, a "creditor" effect that increases the attractiveness of a member country's banks as financial intermediaries, with EMU members increasing lending to all destinations. Thirdly, a "pair-wise" effect, whereby joint membership in the EMU increases the quality of intermediation when both lender and borrower are in the monetary union. This in turn focuses cross-border bank transactions on pairs of countries that are both members of EMU. The "pair-wise" effect appears to be the dominant factor.

Large cross-border banks have substantially increased their role in cross-border credit flows. Prior to the crisis, there were 46 major EU banking groups (out of 8000 banks) that together held two-thirds of total EU banking assets (ECB, 2007). Each of the largest 16 banks had operations in at least a quarter of all EU countries and held at least one quarter of their assets in other EU countries. The share of foreign assets in total assets for the largest banks is high: $82 \%$ for Deutsche Bank, $64 \%$ for Santander, $62 \%$ for UniCredit, $41 \%$ for BNP Paribas and 29\% for Société Générale (Claessens et al., 2010). These banks have been important drivers of enhanced financial integration in Europe. While the balance sheets of EU banks grew by $40 \%$ from 2004 to 2007 , the assets of subsidiaries of euro area banks in other euro area countries grew by $84 \%$ (ECB, 2010a). Large cross-border banking groups played a particularly important role in channelling credit from surplus to deficit countries. These banks operated in multiple markets, and foreign direct investment (FDI) in the financial sector reduced lending rates through greater competition and improved cost efficiencies (Goldberg, 2007; De Blas and Russ, 2008). Large cross-border banks use their internal capital markets to minimise the correlation between the rates of growth of customer loans and deposits (Navaretti et al., 2010). Foreign subsidiaries were able to isolate their lending activities from fluctuations in funds and have been better able to profit from positive upswings in lending conditions in booming countries.

While this form of integration is likely to have brought significant benefits including substantial diversification of risks, it may have contributed in some cases to greater risk-taking. International differences in regulations and tax systems provide arbitrage opportunities that can be exploited through cross-border banking activity. Distortions in corporate governance and regulatory regimes may have provided incentives to expand overseas (CGFS, 2010). There may also be an incentive for bank executives to expand balance sheets through overseas acquisition to increase size-related compensation payments. In addition, international expansion may contribute to a bank becoming "too big to fail" or too costly to unwind, and too complex to be supervised effectively. 
The emergence of large banking groups contributed to home-host supervisory problems, while they became systemically important in several countries of operation. Dependence on subsidiaries as the dominant form of foreign establishment within the euro area (Figure 11) added to the complexity of supervision: for a sample of 30 OECD "systemically important financial institutions" (SIFIs), each has at least 100 majority-owned subsidiaries and more than half have over 500 subsidiaries (Claessens et al., 2010). The cross-border expansion through branches could sometimes lead to potential conflicts as the home country authorities provide branch supervision and the host country authorities are responsible for the stability of the local financial system. These problems were difficult to overcome given the fragmented supervisory architecture in the European Union. When the financial crisis hit, the co-ordination of crossborder rescue and resolution actions proved even more problematic, adding substantively to the fiscal costs of the crisis.

Figure 11. Assets of branches and subsidiaries of euro area credit institutions

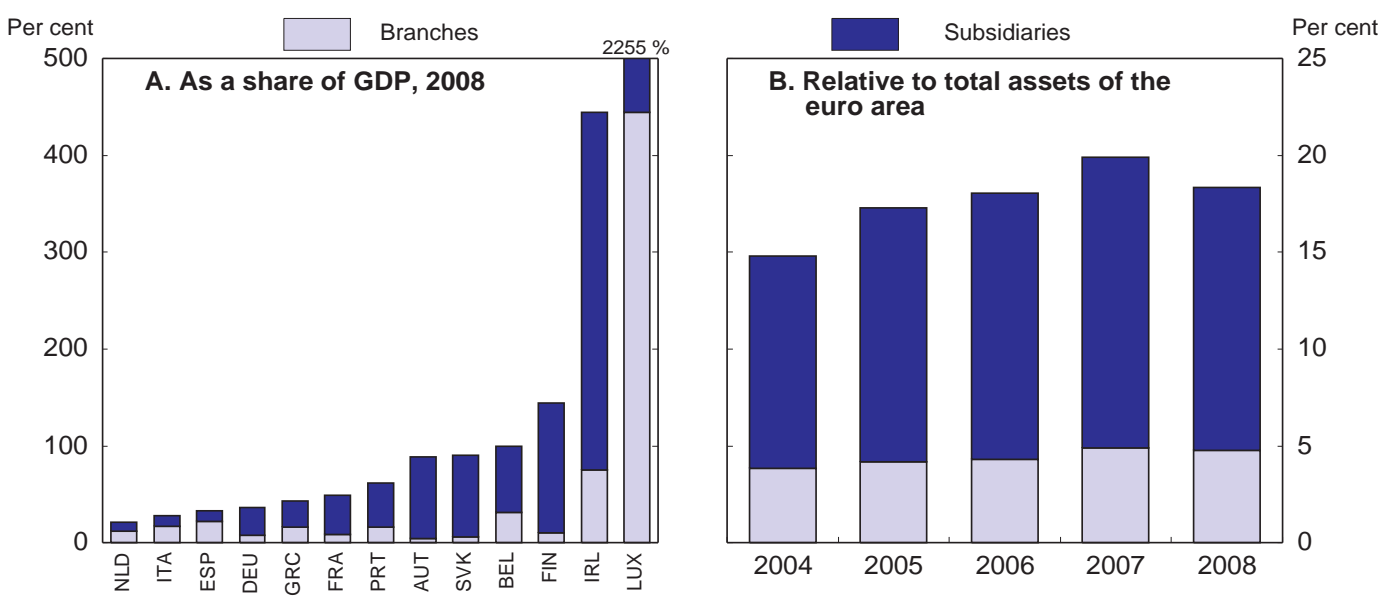

Source: ECB (2010), Structural Indicators in the EU Banking Sector and OECD, OECD Economic Outlook Database.

\section{The financial crisis led to deleveraging and cross-border disintermediation}

Growing concerns about credit risk plunged financial markets into turmoil and the turning of the cycle led to large losses. This had a particularly large impact on economies and banking systems in deficit countries that had experienced strong credit-fuelled booms, as well as increasing pressure on their creditors. The lack of trust between banks and the reassessment of risks led to a sudden deterioration in access to foreign finance for banks in some countries followed by strong disintermediation across borders. Banks raised their lending standards, putting pressure on borrowers, and deleveraged. This forced rapid deleveraging in the private sector, particularly in highly indebted deficit countries with large housing booms. The weakness of banks and the associated downturn led to large fiscal costs. Combined with a reassessment of sovereign risks, this created funding pressures for several countries and forced rapid fiscal adjustments. This unwinding of economic and fiscal imbalances in turn had a further strong feedback effect on the banking sector. Interconnectedness between banking systems across countries and between sovereigns and banks has highlighted problems with local weaknesses spilling over across countries.

During the crisis, there was a dramatic decline in international capital flows and the greatest contraction was in cross-border banking flows (Milesi-Ferretti and Tille, 2010). This was particularly substantial in countries with the largest initial gross banking positions and the most negative net position in external bank assets. International balance sheets of banks contracted by $12 \%$ between the March 2008 peak and the end of 2009, mostly through lower interbank claims. Foreign claims on countries in the euro area fell especially quickly relative to other countries. There was an important shift in the funding strategies of banks as the freezing of wholesale money and interbank markets induced banks to seek more 
stable sources of funding, including through greater competition for deposits (ECB, 2009a). In relation to bond finance, net issuance by banks has declined. Moreover, banks have turned to the Eurosystem as a source of liquidity. To access liquidity, banks have also increased strategic reserves of eligible assets. A two-tier market structure developed after the onset of the turmoil in August 2007, with only large moneycentre banks active in the cross-border money market and other banks relying heavily on domestic counterparties (Cassola et al., 2010). After the collapse of Lehman Brothers in September 2008, the situation further deteriorated with even cross-border trade among the money-centre banks drying up.

In addition, there has been a substantial decline in cross-border M\&A activity in the euro area banking sector (ECB, 2010b). The financial crisis has induced many banks to focus on core activities and markets, with less emphasis on cross-border expansion. In addition, the mergers and acquisitions (M\&A) focus has shifted towards the consolidation of domestic banking systems, in part at the behest of national governments. Rescue packages, as with Fortis, have also tended to lead the reduction in cross-border banking activities and structures. On the other hand, some bank restructurings led to cross-border consolidation like in the Fortis case, where part of the bank was eventually acquired by BNP Paribas.

\section{Upgrading regulation and supervision to reduce risk}

Regulatory and supervisory reforms are necessary to reap benefits from financial deepening and financial integration within the euro area without posing threats to stability. Strengthening of basic microprudential regulation should provide the first line of defence against systemic risks, but effective macroprudential oversight is also needed to prevent excessive credit cycles. Adequate channelling of information and strong co-operation between macro and microprudential supervisors is of the essence to ensure co-ordinated and global assessments of risks and policy responses. Supervisors' actions also need to be better co-ordinated and harmonised. With cross-border banking activity driven mainly by a relatively small number of large banking groups (ECB, 2010b), enhanced home-host co-operation is particularly important. Furthermore, a robust system of cross-border crisis management is required.

Beyond these key areas, several other regulatory and supervisory weaknesses contributed to the accumulation of risks that led to the banking crisis (Wehinger, 2008). These include: weak corporate governance and weak risk management control and inadequate remuneration practices at banks; the dominance of over-the-counter (OTC) transactions; and linkages with the shadow banking system, notably hedge funds and private equity funds. Substantial progress is also needed in these areas and many reforms are already underway, but these issues are not discussed further in this paper.

\section{More robust microprudential regulation should provide the first line of defence}

Microprudential regulation of capital and risk management and supervision were insufficient in the years running up to the crisis to prevent the build-up of systemic risks. Large banks increased their leverage and risk exposures, while the quality of their capital gradually eroded. While many banks held capital well in excess of minimum requirements, large dividend payments, share buy-back programmes and discretionary bonus payments weakened capital positions at the onset of the financial crisis, even as the outlook for financial sector was already deteriorating. As a result, the ability of the banking system to absorb the resulting trading and credit losses was impaired. Furthermore, the capital framework did not adequately cover all risks. Important on- and off-balance sheet risks, as well as derivative exposures, were not captured adequately. These proved to be highly destabilising during the financial crisis (Blundell-Wignall et al., 2009). This was aggravated by risk-management practices, with regulatory dependence on credit rating agencies contributing to less effective internal credit screening and due diligence (Persaud, 2008). Liquidity regulations were relatively under-developed and their harmonisation limited. Many banks held insufficient liquidity buffers and were strongly dependent on wholesale 
financing through interbank deposits and securities funding. This proved devastating for such banks during the crisis when liquidity in the interbank system dried up.

Table 1. Bank capital: current and future requirements

Per cent of risk-weighted assets

\begin{tabular}{lccr}
\hline & Current requirement & $\begin{array}{c}\text { Requirement in } \\
2015^{2}\end{array}$ & $\begin{array}{c}\text { Requirement in 2019 (incl. } \\
\text { conservation buffer) }\end{array}$ \\
\cline { 2 - 4 } Common equity tier 1 capital & 2 & 4.5 & 7 \\
Tier 1 capital & 4 & 6 & 8.5 \\
Total capital & 8 & 8 & 10.5 \\
\hline 1. Before the application of stricter capital definitions. & & \\
$2 . \quad$ After the application of stricter capital definitions. & & \\
Source: Basel Committee on Banking Supervision. &
\end{tabular}

Several of these issues have been addressed at the international level by the package of reforms agreed in September 2010 by the Group of Governors and Heads of Supervision, the oversight body of the Basel Committee of Banking Supervision. Despite relaxation of more ambitious initial proposals and the long implementation periods, the package known as "Basel III" provides for a substantial strengthening of banking sector stability in the coming years. The most important elements include improving the quality, consistency and transparency of the capital base, and the introduction of leverage and liquidity ratios. When fully implemented on 1 January 2019, the regime will have the following elements:

- The recognition in common equity of investments in financial institutions, mortgage servicing rights and deferred tax assets from timing differences will be limited to $10 \%$ of common equity, the highest form of loss-absorbing capital. Moreover, any amount by which the aggregate of these three items exceeds $15 \%$ of common equity is to be deducted.

- The minimum requirement for common equity will be raised from the current $2 \%$ of risk-weighted assets, before the application of regulatory adjustments, to $4.5 \%$ after the application of stricter adjustments (Table 1).

- The tier 1 capital requirement, which includes common equity and other qualifying financial instruments based on stricter criteria, will increase from $4 \%$ to $6 \%$.

- The capital conservation buffer above the regulatory minimum requirement will be calibrated at $2.5 \%$ and met with common equity after the application of deductions. Banks will face increasing restrictions on the distribution of earnings and bonus payments, when their capital ratios fall towards minimum requirements.

- A non-risk-based leverage ratio will serve as an additional safeguard against attempts to game the riskbased requirements, and help address model risk. A minimum tier 1 leverage ratio of $3 \%$ will be tested during a parallel-run period, and would be introduced as a requirement in 2018 based on appropriate review and calibration. To ensure comparability, the leverage ratio for regulatory purposes will be based on an internationally harmonised definition, which is necessary due to significant differences in accounting methodologies across jurisdictions (Box 3).

- Liquidity coverage and net stable funding ratios will be introduced and supported by a common set of monitoring metrics to assist supervisors in identifying and analysing liquidity risk trends at both the bank and system-wide level. 


\section{Box 3. Comparison of leverage in the United States and the euro area}

Differences in accounting standards complicate international comparability of leverage ratios and relative riskiness of banking systems in the United Sates and the euro area. For example, legally endorsable master netting agreements with single counterparties can be deducted from assets in the United States (based on US GAAP accounting rules), but not in the European Union (based on IFRS accounting rules). Pro-forma balance sheets in the two standards show significant differences in leverage ratios, and the differences in accounting standards lead to very different conclusions about relative leverage of banks (Table 2). This is because banks optimise their balance sheets according to the regulatory standards they are facing. It is therefore pertinent to use a common definition of the leverage ratio as it was agreed by the Group of Governors and Heads of Supervision in July 2010.

Table 2. Pro-forma leverage ratios under GAAP and IFRS

\begin{tabular}{lcccc}
\hline & \multicolumn{2}{c}{ JP Morgan Chase } & \multicolumn{2}{c}{ Deutsche Bank } \\
\hline & US GAAP & Pro-forma IFRS & IFRS & Pro-forma US GAAP \\
\hline Total assets ${ }^{1}$ & 2032 & 3517 & 1501 & 891 \\
Equity $^{1}$ & 165 & 165 & 38 & 38 \\
Leverage (total & 12 & 21 & 40 & 23 \\
assets/equity) & & & \\
\hline 1. USD million for JP Morgan Chase data and EUR million for Deutsche Bank data relative to total assets and equity. \\
Source: Banker reports, OECD.
\end{tabular}

However, the implementation timetable has been heavily back-loaded to mitigate potential adverse impacts of the new regulations on lending and growth in the shorter term (Box 4). More restrictive capital definitions will be phased in gradually from January 2013 over a period of 10 years. The implementation of the minimum capital ratios will be phased in from January 2013 to be fully implemented by 2015. After that is complete, a conservation buffer will be phased in by January 2019. The leverage ratio will be tested starting in 2013 and might be integrated into capital requirements in 2018, based on a review and calibration. After an observation period beginning in 2011, the liquidity coverage ratio (LCR) will be introduced on 1 January 2015, while the Net Stable Funding Ratio (NSFR) may be effective from 2018.

The risk coverage of the capital framework will also be strengthened. In addition to the trading book and securitisation reforms, the Basel Committee agreed to strengthen capital requirements for counterparty credit risk exposures arising from derivatives, repos and securities financing activities. These enhancements, to be implemented at the end of 2011, will strengthen the resilience of individual banking institutions and reduce the risk that shocks are transmitted from one institution to the other. The strengthened counterparty capital requirements will increase incentives to move OTC derivative activities to central counterparties and exchanges.

The new Basel III accord now needs to be transposed into the EU Capital Requirement Directive (CRD) to become the backbone of the microprudential regulatory architecture in the European Union. The European Commission will present legislative proposals to implement Basel III in the CRD Directives in the first quarter of 2011. Some consideration should be given to an accelerated phasing-in. In addition, the upgrading of financial oversight needs to go beyond the Basel III accord in some areas, including concentration risks that need to be better addressed by EU supervisors, in particular to motivate banks to exploit risk diversification opportunities in the euro area more effectively. The strength of local credit cycles would also be reduced and market discipline improved, if risks related to geographic concentration of lending, including to sovereign debt, were appropriately managed. More fundamentally, Basel III does not fully address the problem that the "promises" that make up any financial system are not treated equally and continues to allow arbitrage between on- and off-balance sheet items (Blundell-Wignall and Atkinson, 2010). 


\section{Box 4. The macroeconomic impact of the new Basel capital requirements}

Estimates by the Macroeconomic Assessment Group (MAG) of the Financial Stability Board (FSB) and the Basel Committee on Banking Supervision (BCBS) show that a 1 percentage point increase in the ratio of capital to risk-weighted assets will lead to a decline in the annual GDP growth rate of -0.04 percentage points during a four year implementation period. The Basel III capital requirements, agreed by the Group of Governors and Heads of Supervision of the BCBS, raise the minimum common equity ratio by $2.5 \%$ and the Tier 1 capital ratio by $2 \%$ by 1 January 2015. If banks choose to maintain the current size of discretionary capital buffers, this would have an impact on the annual GDP growth of about -0.1 percentage points during this period. A similar impact can be expected between 2015 and 2018, when a capital conservation buffer of $2.5 \%$, is phased in. The actual impact is likely to be even lower as banks might use their discretionary capital buffers, which they hold in excess of the current regulatory minimum, to offset part of the required increase in regulatory capital. On the other hand, these estimates do not take into account the impact of the new definition of capital and new risk weights used to calculate capital adequacy ratios, but this additional impact will be small.

\section{Macroprudential policy should be developed}

The crisis exposed failures in mitigating systemic risk, or "the risk that financial instability becomes so widespread that it impairs the functioning of a financial system to the point where economic growth and welfare suffer materially" (ECB, 2009c). The role of such macroprudential policy is mainly preventive, and should be distinguished from crisis management and crisis resolution. However, there are important links between these policies. For example, weakness in crisis management and resolution, for example bailouts with too mild conditions, might increase systemic risk through greater moral hazard. Interactions with monetary policy are also important. While monetary policy is aimed at maintaining medium-term price stability, macroprudential policy will remain the primary tool to manage financial cycles, and by preventing excessive cycles in asset prices and balance sheets, it can contribute to longer-term price stability. Moreover, financial stability is needed to ensure appropriate monetary policy transmission mechanisms.

There are two intertwined goals in mitigating systemic risk (CGFS, 2010):

- Strengthening the resilience of the financial system to shocks and economic downturns.

- Leaning against the wind or limiting the build-up of financial risks (including those emerging from innovation and changes in the structure in the financial sector) that can pose a risk to the financial sector and the wider economy.

There is a widespread belief among central banks and supervisors that macroprudential policy can be at times effective, but there are also clear limits as to what could be achieved (CFGS, 2010). Enhancing the resilience of the financial system through the use of instruments based on standard microprudential tools is considered more likely to be feasible than more general efforts to lean against the wind. This appears, for example, to be the experience of Spain during the housing boom and the financial crisis. Macroprudential policy is therefore strongly complementary to other policies. A boom in housing markets, for example, might be best addressed through a combination of macroprudential policies that tighten lending standards to this sector and changes in tax incentives and barriers to housing supply.

The identification of systemic risks is a necessary condition for effective macroprudential policy. A battery of tools has been proposed to identify these risks (ECB, 2010c). Apart from exogenous shocks, there are two endogenous dimensions of systemic risks (Borio, 2003):

- A cross-sectional dimension related to the interconnectedness between financial institutions, including systemically important ones.

- A time dimension related to the build-up of financial imbalances through cycles. 
Macro stress tests evaluate the resilience of banking sectors to large but plausible external shocks. Contagion and spillover models assess the cross-section dimension of systemic risk by analysing channels and speeds of transmission of shocks across the system. Early warning models provide measures of risk due to emerging financial imbalances. Finally, financial stability indicators provide measures of the actual degree of instability at any given moment.

Measures to mitigate systemic risks should deal with vulnerabilities stemming from financial markets (margin requirements and haircuts) and market infrastructures (central counterparties), as well as banks. In terms of the banking system, there are two targets for these measures:

- Bank balance sheets. These measures aim primarily at strengthening the resilience of the banking sector, but also cover the supply of credit and hence the build-up of financial risks. The cross-section dimension of systemic risk can be limited through a differentiated treatment of counterparty risk exposures, and capital and liquidity surcharges on systemically important institutions. Measures addressing the time dimension of systemic risk include minimum capital requirements, forwardlooking provisioning, capital buffers and cyclical capital add-ons. These issues can be also addressed through a risk-based levy that would increase the cost of risk for systemic institutions. However, a levy does not increase the loss-absorbing capacity of the institutions, since the funds are not held by firms but are directed either to a dedicated fund or the general budget.

- Credit demand. These measures affect directly the accumulation of exposures, and often aim at preventing excessive build-up of leverage in specific sectors of the economy such as housing and construction. These measures include limits on loan-to-value (LTV) or loan-to-income (LTI) ratios, collateral rules and collateral haircuts. The additional benefit of these measures is to give a clear signal about emerging systemic risks.

Most of these quantitative measures are based on adapting standard microprudential regulatory rules to the system level. Measures more tilted at leaning against the wind tend to be more macroeconomic in nature in their application (applied across all institutions), and dynamically adjustable (to promptly address changes in the degree and character of systemic risks). Combinations of balance sheet and demand measures are possible. For example, according to the CRD, lending with high LTV ratios would imply capital surcharges, while choosing the appropriate margin would be left to national discretion.

\section{Systemically important institutions need stricter regulation and more intrusive supervision}

Systemically important financial institutions (SIFIs) played a major role in the financial crisis (ECB, 2010c). They contributed directly to the cross-section dimension of systemic risk, by increasing the complexity and interconnectedness of financial markets, and risk of contagion in the system. They tended to play a disproportionate role in the accumulation of imbalances, because of their role in cross-border lending and faster adoption of financial innovations. Moral hazard associated with SIFIs being too big or too interconnected to fail may have lowered default risk premiums and encouraged risk-taking and the expansion of balance sheets (Baker and McArthur, 2009). As these banks are often very large when compared with national economies, they can easily make a significant contribution to financing rapid and excessive credit growth on a national scale. Despite these special characteristics, large cross-border institutions have not been subject to specific regulatory measures.

The contribution of a bank to systemic risk is the product of its systemic importance and its own riskiness. While the methodology for assessing individual institution's risks is relatively well understood, the measurement of the systemic component poses challenges. The emerging consensus is that systemic importance can be assessed along three basic dimensions: size, interconnectedness and substitutability (ECB, 2010c). However, several qualitative aspects also need to be taken into account, making any classification tentative. It is important to view systemic importance as a continuous measure. Creating a finely granular ranking is preferable to a closed list of systemically important banks that would likely lead 
to distortions in regulatory, supervisory and market perceptions between institutions on both sides of any arbitrary threshold.

Specific macroprudential measures directed at the SIFIs have two complementary objectives. The first is to reduce their systemic importance by changing the business model and simplifying resolution. This can be achieved by legally separating and reducing the size of different activities, such as proprietary trading, private equity and hedge fund investments. These considerations were reflected, for example, in the Volcker rule in the United States. Tax surcharges on large banks can also contribute to dealing with systemic risk by recovering the "too big to fail rents", and offsetting their impact on the cost of risk. The development of recovery and resolution plans contributes to overcoming obstacles to orderly resolution. The second objective is to reduce the probability of default given the existing business model. Additional prudential requirements can contribute to both objectives at the same time. However, Basel II was favourable for large banks as their capital requirement ratios were relatively low, implicitly promoting size (Jokipii and Milne, 2006). The forthcoming Basel III proposals are expected to change this by penalising size and complexity by requiring higher loss-absorbing capacity. This would include combinations of capital surcharges, contingent capital and bail-in debt. Separation through regulation is a possible scenario, with gradual spinning-off of non-core banking activities.

More effective and intrusive supervision and improved resolution mechanisms that minimise the risks of moral hazard are essential for dealing with SIFIs. While the additional prudential requirements are attractive, institutional complexity often reflects attempts to overcome regulatory requirements or taxation. Therefore, creating additional levels of anti-complexity regulations without enhanced supervision could lead to perverse outcomes. Moreover, while there is a general consensus about the supervisory toolkit available to reduce systemic risks of SIFIs, choosing the right tool for a given institution is not straightforward (ECB, 2010c). A decision about the application of capital surcharges, contingent capital and bail-in debt and more intrusive supervision requires close co-operation between the home authority and host authorities, with an important role played by the supervisory college. However, such decisions should be peer-reviewed and co-ordinated under the auspices of the European Banking Authority (EBA) to prevent divergent supervisory practices and an uneven playing field. Reinforced corporate governance principles and adequate incentives are also important to mitigate excessive risk appetite.

\section{Increasing cyclical resilience}

Pro-cyclical amplification of shocks through banks and financial markets was one of the key systemic risks leading to the financial crisis (Penetta et al., 2009). A tendency to underestimate risk in good times and overestimate it in bad times increased the potential for credit and asset market booms and busts (OECD, 2010). While the aggregate effects in the euro area were not especially marked, this tendency was very strong in some individual euro area countries that faced destabilising real interest rates and large capital inflows, thereby contributing to economic imbalances.

The regulatory framework contributed to pro-cyclicality through several channels (BCBS, 2010): accounting standards for both mark-to-market assets and held-to-maturity loans; margining and provisioning practices; and leverage among financial institutions, firms and consumers. Pro-cyclicality has potentially been also magnified through cyclicality of minimum capital requirements that was linked to higher risk sensitivity of Basel II capital requirements (Lowe, 2002; Borio and Shim, 2007). As banks and supervisors failed to fully appreciate risks related to emerging exposures, capital requirements were kept too low, while evidence suggests that bank lending might become particularly cyclical when banks are both under-capitalised and illiquid (ECB, 2009c).

Pro-cyclicality was not addressed adequately in the supervisory process, despite safeguards suggested by the Basel Committee to mitigate the cyclical consequence of Basel II. These included long-term horizons in the estimation of default probabilities, the introduction of loss-given-default estimates, and the 
recalibration of risk functions. Supervisors could also impose higher capital standards, based on stress tests that assumed increased riskiness of credit portfolios. A review to assess the impact of Basel II on the cyclicality of capital was also put in place. However, supervisory process remained driven by a point-intime rather than a through-the-cycle perspective.

To mitigate pro-cyclicality, Basel III includes several changes in the regulatory framework:

- A leverage ratio to provide a basic backstop against excessive increases in total assets during upswings.

- Capital conservation buffers to increase resilience across business cycles by promoting more energetic rebuilding of capital in the recovery and its protection in a downturn.

- Changes in the methods of calculating the probabilities of default (PD) to dampen excess cyclicality of internal ratings-based minimum capital requirements.

- A larger role for forward-looking provisioning to link provision to expected losses in a downturn, which can be very large after strong credit growth in an upturn (Box 5). This role needs to be supported by a change in accounting standards that adjusts principles of fair representation to the strongly cyclical reality of the banking business. It is also important that tax systems do not penalise higher levels of provisioning that reflect prudential approaches towards losses.

\section{Box 5. Macroprudential policy in Spain}

The central bank of Spain, which was also the financial supervisor, used macroprudential policy to address the accumulation of financial risks during the upswing preceding the current crisis. The policy had two objectives: constrain credit growth and protect Spanish banks from future losses, drawing on the lessons of past banking crisis experienced in Spain in the late 1970s. A system of dynamic (or statistical) provisioning was introduced in July 2000 as a key tool to achieve these objectives. Total provisions under this system are the sum of specific and generic components. The specific provisions, calculated according to the IFRS accounting standards, reflect the riskiness of portfolios based on current losses. These tend to be strongly pro-cyclical. While credit loss ratios tend to be compressed in good times, accumulated provisions are often insufficient expost, and provisions increase rapidly in a downturn. Forbearance among banks and supervisors in recognising bad loans may aggravate this pro-cyclicality. The generic provision in Spain was designed to counter-balance these effects by bringing the ratio of total provisions to credit in line with long-run expected losses, and therefore maintaining a sufficiently high bank capitalisation to prevent a credit crunch in a downturn.

Taking the two types of provisions together, the dynamic provisioning formula has effectively two components: the first linked to the stock of credit, ensuring a stable provisioning ratio, and the second linked to the growth of credit, enforcing counter-cyclicality. The weights on these two components were linked to across-the-cycle risk estimates, derived either from internal models or a benchmark model provided by the central bank. The basic formula is given below:

total . provisions ${ }_{t}=$ specific $_{t}+$ generic $_{t}=$ specific $_{t}+\alpha \Delta C_{t}+\left(\beta-\frac{\text { specific }_{t}}{C_{t}}\right) C_{t}=\alpha \Delta C_{t}+\beta C_{t}$

The introduction of the dynamic provisioning in its original form had a strong counter-cyclical effect but this was weakened after its reform in 2004 (Figure 12). Some banks released part of accumulated provisions, while others stabilised provisions despite continued rapid credit growth. During the financial crisis, when specific provisions surged, reductions in generic provisions smoothed the increase in the total provisioning ratio, but failed to stabilise it. One reason was a high risk aversion justified by the extraordinary depth of the crisis; however, existing provisions might also have been insufficient, partly due to the introduction of the cap. Therefore, the 2004 reform illustrates the difficulties in using macroprudential tools prior to the crisis, when their role and effectiveness was contested not only by the banks, but also by the international accounting bodies and fiscal authorities (Fernandez de Lis and Herrero, 2010). The result was a system that allowed for a less cyclical loan loss provision, but which did not eliminate pro-cyclicality completely. It was more effective in creating a cushion in the good times than in discouraging rapid credit growth or rises in house prices. 


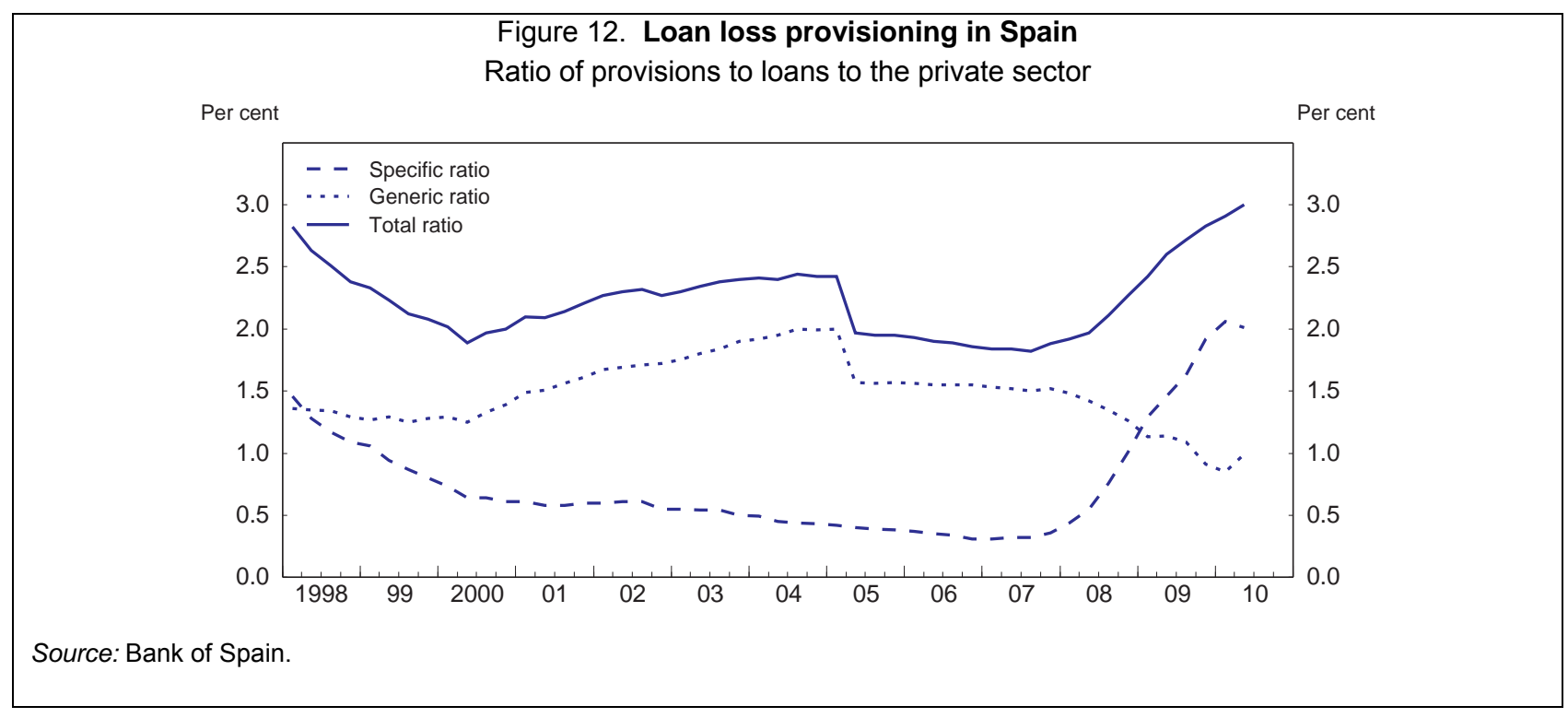

Additional counter-cyclical capital buffers should be set to secure banks against risks from excessive credit growth. One important weakness of the Basel II regulatory framework was the lack of a link to the macro-financial environment in which banks operate. While several observers pointed to risks of excessive credit growth rates, for example related to housing booms, capital requirements did not reflect these risks. The approach based purely on supervisory discretion proved largely ineffective. An alternative approach based on a centrally determined rule with flexible implications is now reflected in the Basel III agreement on counter-cyclical buffers. The primary objective is to ensure that individual banks and banking systems accumulate capital during periods of rapid credit growth, so that they remain solvent, and are able to continue providing credit to the economy during a subsequent downturn. However, the buffer also has the potential to lean against excessive credit cycles by raising the cost of capital through additional capital requirements. According to Basel III, counter-cyclical buffers within zero to $2.5 \%$ of common equity or other fully loss-absorbing capital will be implemented according to national circumstances.

The proposed counter-cyclical buffer links capital requirements to deviations from long-term trends in credit-to-GDP ratios in different jurisdictions. Given the limitations of any simple rules, the authorities are expected to apply judgement in setting the buffer in their jurisdiction, but the credit-to-GDP guide will provide a common reference point. The buffer is not symmetrical and is expected to remain zero most of the time. Only evidence of excessive credit growth will prompt decisions for capital add-ons, and banks will be given 12 months to meet these requirements. On the contrary, reductions in buffers will take immediate effect to reduce the risk of a credit crunch. The counter-cyclical buffer operates on the principle of jurisdictional reciprocity. While capital add-ons applicable to counterparties/borrowers in each jurisdiction are decided by the respective authorities, they are binding for all lending banks irrespective of their country of residence. This ensures that the buffer add-on will create a level playing field for banks from different countries and, crucially, that capital requirements are not circumvented through cross-border lending. However, supervision will need to be strengthened to prevent other forms of circumvention, including lending through foreign non-financial subsidiaries or through expanded off-balance sheet items. Linking counter-cyclical buffers to the location of collateral can be useful in preventing regulatory avoidance.

When implemented, these Basel III proposals could be complemented by other counter-cyclical instruments as part of the Pillar 2 supervisory process. First, capital requirements could be linked to the growth rate of credit in particular sectors such as housing and construction. Secondly, minimum loan-tovalue and loan-to-income standards could be used as they proved effective in addressing excessive credit 
cycles in several countries (CGFS, 2010). Thirdly, strengthening vigilance, peer review and decisive enforcement of the supervisory processes remain critical conditions for ensuring less pro-cyclical banking sectors in the future.

\section{The European Systemic Risk Board}

Successful macroprudential policy requires an effective institutional framework for implementation. Before the crisis, it was not clear which institution in the existing supervisory architecture was responsible for monitoring and mitigating systemic risks in the integrated European financial system. The ECB played only a peripheral role in financial oversight (Hoeller and Rae, 2007). It did not have a privileged access to supervisory data and, while it regularly monitored financial stability in the euro area, there was a gap between systemic risk identification and the possilibity of a policy response. Raising awareness about growing risks prior to the crisis failed to influence behaviour of market participants and to contain these risks $(E C B, 2010 \mathrm{c})$. The crisis and the recognition of this problem led to the creation of the European Systemic Risk Board (ESRB), working in tandem with the European Supervisory Authorities (ESAs), including the European Banking Authority (EBA), as part of the new European System of Financial Supervision. In the new supervisory architecture, the ESRB will provide systemic risk assessments, issue risk colour-coded warnings, address recommendations to the EU and national authorities with specified timelines for the relevant policy response, including legislative initiatives, and monitor their implementation (Figure 13). National supervisors and central banks should also strongly strengthen macroprudential supervision at national level.

Figure 13. European system of financial supervision

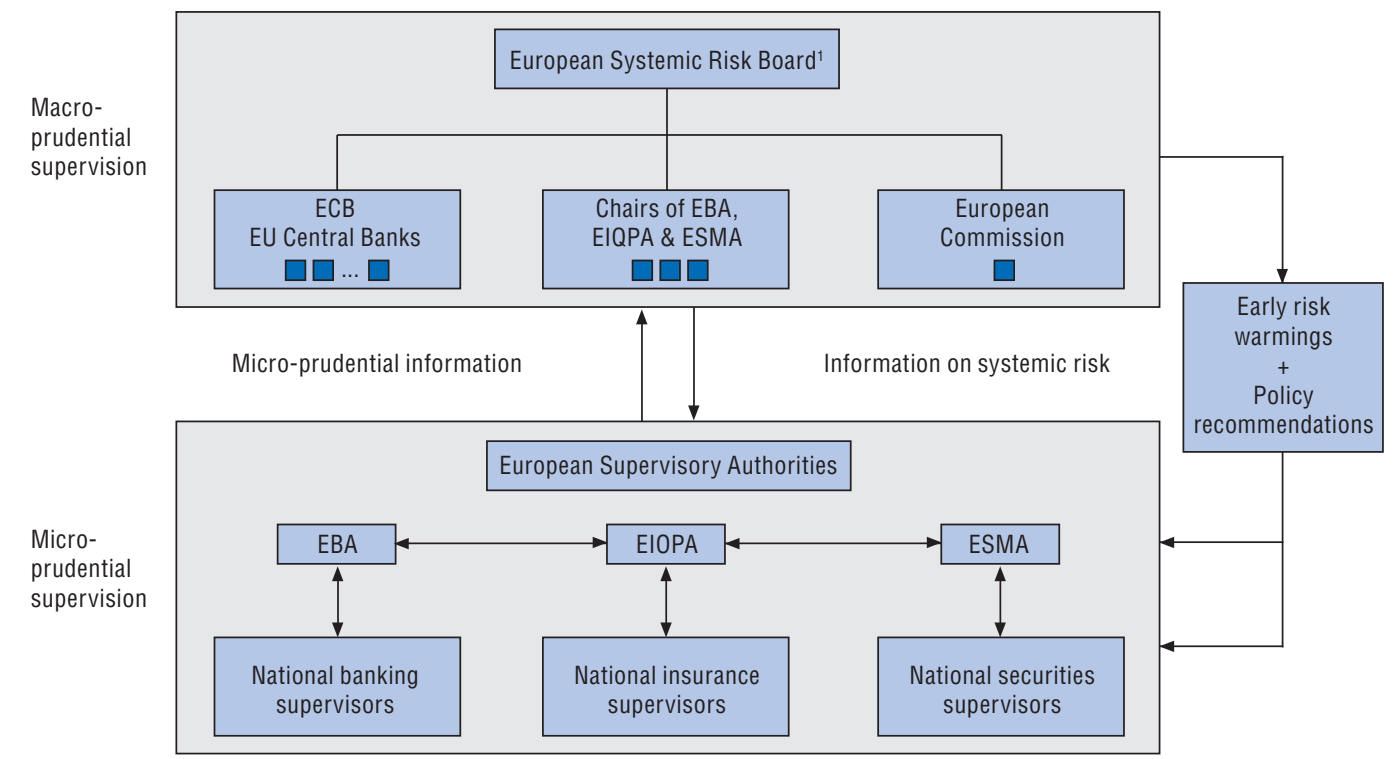

1. Advisory Scientific Committee and Advisory Technical Committee will also be represented in the General Board of the ESRB with voting rights, while national supervisors and the Economic and Financial Committee will be represented without voting rights.

Source: ECB (2010), Financial Integration in Europe, April.

The ESRB will be established as a body without legal personality and with rather loosely defined competencies. The way it develops in practice and the reputation it achieves will be crucial to its effectiveness. The general board of the ESRB will consist of the ECB president (as the Chair, at least in the first five years of operation) and Vice-President, the governors of all EU central banks, a member of the European Commission, the chairpersons of each of the three European Supervisory Authorities, the chair of the Advisory Technical Committee and the Chair and two Vice-Chairs of the Advisory Scientific Committee as voting members, while the representatives of the national supervisory authorities and the 
President of Economic and Financial Committee will be non-voting members. The ECB will provide the secretariat and the analytical, logistical, administrative and statistical support, also drawing on advice from national central banks and national supervisors. As a rule, decisions on warnings and recommendations will be taken by a simple majority rule, but it is imperative to develop an effective internal decisionmaking process to avoid blockages and delays due to the size and complex composition of its general board. The ESRB will also have a consultative role in declaring financial emergencies. To be effective, the ESRB needs full access to supervisory information and sufficient resources to develop and keep refining the full suite of models to identify different dimensions of systemic risks. Similarly, the new ESAs will also need access to the relevant data produced by the ESRB, therefore strong information channels and coordination will have to be set up.

The ESRB does not have binding powers, and the effectiveness of the "act or explain" process hinges crucially on the political will to act. ECOFIN should help enforce ESRB recommendations by pressuring non-complying countries. It is of great importance that the ESRB is allowed sufficient independence, its mandate is clearly defined, and that it acts in a robust way to withstand opposition to its warnings and recommendations that are likely to be strongly unpopular in national capitals and in banking headquarters. One risk is that the objectives of the ESRB could be overly ambitious and hence contribute to fostering a false sense of security among European authorities, which could undermine credibility of the newly created institution. On the other hand, the ESRB should seek to interpret its mandate broadly and consider issues related not only to the resilience of the banking system and other financial sectors, but also to macroeconomic stability because macroprudential instruments are a better way of dealing with some macroeconomic and financial tensions than monetary policy.

The ESRB and the EBA should work closely together to make sure that microprudential and macroprudential policies reinforce each other, and that European rules, tools and policies address emerging risks. This should involve a regular exchange of information and continuous dialogue with the ESRB issuing warnings and recommendations, when simple rules fail to address emerging challenges, and supervisory processes are not effective. Both institutions should jointly calibrate concentration, systemic importance and counter-cyclical regulation, taking into account country-specific and institution-specific systemic risks. The EBA will elaborate technical standards to guide national decisions and ensure jurisdictional reciprocity in the use of LTV/LTI limits and similar supervisory instruments.

The implementation of macroprudential policy, including its counter-cyclical and anti-contagion dimensions, should reflect a guided discretion approach that combines framework rules with a certain degree of supervisory discretion. While binding rules maximise credibility and predictability of the supervisory system, it is extremely difficult to construct rules that address every possible contingency. Binding rules are also likely to be blunt, and hence reduce incentives to improve banks' risk management frameworks (Borio, 2003). It is also likely that each subsequent credit cycle might be different so that too specific or strict rules might fail to capture its changing character. On the other hand, purely discretionary supervisory decisions either at individual bank or financial system levels might appear ad hoc and arbitrary, and lead to distortions to the level playing field. Such decisions are also likely to be more sensitive to political pressures, with the risk that authorities might wait too long before taking unpopular actions in response to cycles. Guided discretion is therefore the most promising approach to promote counter-cyclicality and minimising risks of contagion, with quantitative tools creating a presumption that the authorities will act in well-defined circumstances, although with judgment allowing some flexibility. Adequate monitoring and peer review of implementation of the agreed guidance will also help to ensure harmonised supervisory outcomes.

The importance of national economic and financial imbalances and contagion suggests that national macroprudential arrangements need to be put in place, alongside the ESRB. While imbalances even in small countries may lead to area-wide risks to the financial system, there may be cases where problems are 
more local or become more quickly apparent to the national authorities. In addition, macroprudential policies are one of the key tools to deal with national imbalances, particularly in a monetary union. A set of national institutions is required to assess the situation and take action. Many countries have already explicitly assigned financial stability tasks to designated national authorities, very often located within the national central bank. EU bodies such as the ESRB and the ESAs should support national policies, where appropriate, by ensuring that all EU financial institutions abide by the measures taken with respect to activities in a particular jurisdiction.

\section{An effective system of cross-border supervision is needed}

A unique combination of integrated financial markets and nationally organised supervision (Box 6) has created severe challenges for effective supervision in the European Union. Integration means that contagion risks are increased and assessing counterparty risk is complicated. Large cross-border groups can be systemically important in several countries, while national supervisors tend to focus on local risks. Conflicts between home and host supervisors might emerge. Ensuring the level playing field requires increased cross-border harmonisation in rules and supervisory practices. Multiple and non-harmonised national supervisory rules and practices also imply high costs of regulatory compliance for cross-border banks.

\section{Box 6. The supervisory architecture prior to the crisis and the reforms}

Cross-border supervisory challenges in Europe were addressed by granting a leading role to the home country supervisor in the Second Banking Directive in 1993. Home supervisors are responsible for licensing, regulating and supervising cross-border branches, although host countries are given the role of protecting depositors in emergency situations and retain control of liquidity in branches. Host supervisors are responsible for subsidiaries that are set up under local law, and an attempt to retain control over domestically-active institutions contributed to the emergence of subsidiaries as the dominant form of foreign establishment in Europe. The role of colleges of supervisors was increasing gradually, since the Capital Requirement Directive mandated their establishment as frameworks to reach agreement on key supervisory tasks, including ongoing supervision, crisis prevention and crisis management.

The "Lamfalussy" process was set up in 2004 to improve institutional co-ordination for the supervision of international banking and insurance groups. At the first level, the Commission, the European Council and Parliament draw up proposed directives. At the second level, technical committees for implementing these directives are set up. At the third level, three European committees of supervisors are responsible for co-ordination and for advising the national supervisory authorities in banking (the Committee of European Banking Supervision, CEBS), securities (the Committee of European Securities Regulators, CESR) and insurance (the Committee of European Insurance and Occupational Pensions Supervisors, CEIOPS). At the fourth level, the European Commission is responsible for overseeing the transposition of directives into national legislation.

In the wake of the financial crisis, the de Larosiere report (2009) found the "embryonic" agreements developed by the third-level committees ineffective, citing a lack of frankness, mutual confidence and co-operation among national supervisors. New EU legislation is intended to strengthen the role of these institutions, by upgrading them to the status of authorities, including the European Banking Authority (EBA). In order to ensure cross-sectoral consistency in activities, a Joint Committee will co-ordinate the functions of the three new supervisory authorities in relation to financial agglomerates and other cross-sectoral matters. The EBA will be granted several tasks to address some of key cross-border supervisory problems:

- Developing proposals for technical standards.

- Resolving cases of disagreement between national supervisors, where legislation requires them to co-operate or to agree.

- $\quad$ Ensuring the consistent application of technical Community rules (including through peer reviews).

- A co-ordination role in emergency situations.

A single integrated EU supervisor for large cross-border banks might be the first best supervisory arrangement in the long run; however complexities and problems related to this model, notably difficulties in resolving cross-border burden-sharing, are important, and a review of the new supervisory arrangements is foreseen after at most three years to determine whether further steps towards more integrated supervision are needed. 


\section{The European Banking Authority needs sufficient powers and resources}

The European Banking Authority should ensure a high level of consistency in supervisory rules and practices. Considerable cross-country differences in legal and regulatory frameworks persist and can be harmful for a level playing field in European banking. National discretion is preserved by national specificities in transposing directives. There are almost 100 specificities for the Capital Requirements Directive (Kager, 2006). The practice of adding further national requirements over and above those prescribed by EU directives ("gold-plating") is an additional problem. Many technical rules are determined at national level. This creates risks of regulatory arbitrage and regulatory competition. Home supervisors of various cross-border groups might have different views on major supervisory issues, leading to different outcomes for groups in direct competition. Enhancing supervision implies that:

- Harmonisation requires the elimination of options and gold-plating. The EBA will issue binding technical standards that are directly applicable. It is important that the application of these powers covers a sufficiently wide set of regulatory settings to achieve something close to a single rule book. Looking forward, newly emerging issues will be immediately tackled by the EU framework to prevent adding new discrepancies. New regulations should be more specific and leave less supervisory discretion.

- Robust and transparent decision-making procedures at the EBA are necessary to allow a progress towards a single rule book. Qualified majority voting will be used for decisions on technical standards and guidelines. All other decisions will be taken by simple majority. The process by which the European Commission has to approve binding technical standards proposed by the EBA (in certain cases countries and the European Parliament can raise objections) should be implemented in a way that avoids excessive delays.

- The EBA will be empowered to investigate alleged incorrect or insufficient application of EU law by national supervisors, concluded by a recommendation. In case of non-compliance, the European Commission would be empowered to issue the formal opinion, take the necessary action, and as a last resort and in exceptional circumstances, the EBA would be empowered to adopt decisions addressed directly to financial institutions.

The EBA will have binding mediation powers to address potential differences in the interests of home and host supervisors. When a domestic institution expands abroad through branches, the home supervisor might have a tendency to underestimate risks created for host countries, as was most vividly demonstrated by the expansion of Icelandic banks. This is due to the agency problems where the home country provides branch supervision and the host country is responsible for the stability of the system, while information is asymmetric (Hoeller and Rae, 2007). Yet, host countries have only a limited ability to challenge the decisions and actions of the home supervisors. In particular, the peer review process developed within the level 3 committees proved ineffective (de Larosière Group, 2009). Similarly, the home country supervisors did not have effective means for challenging decisions of the host supervisors, particularly to protect the stability of cross-border banking groups. Notably, the Committee of European Banking Supervisors did not have the powers to play a dispute resolution role. These dispute resolution powers will be granted to the EBA. Following a conciliation phase, the EBA would be empowered to make binding settlement and require the national supervisory authority to take specific actions, and, in case of non-compliance, to adopt decisions addressed to individual financial institutions. Supervised institutions should have a right to appeal directly to the EBA and a peer review process should be strongly enhanced to ensure consistency in supervisory decisions.

The major role of the EBA will be to strengthen the oversight and co-ordination of colleges and formulate detailed guidelines for their functioning. While colleges started to play a positive role in 


\section{ECO/WKP(2010)84}

improving co-operation in information sharing among national supervisors, their role prior to the crisis remained limited. Colleges for major cross-border banks are obligatory only since December 2009 and all cross-border banking groups will need to have a college of supervisors in place by the end of 2010 . Ensuring consistency among colleges will be complicated by their large number: there are currently over 120 colleges (de Larosière Group, 2009). In responding to these challenges:

- The EBA will have powers to collect and share all relevant information in co-operation with the competent national authorities and colleges; initiate and co-ordinate EU-wide stress tests; promote effective and efficient supervisory activities; oversee the tasks carried out by the competent authorities; request further deliberations of a college; require the consolidating supervisor to schedule a meeting of the college or add a point to the agenda of such a meeting; develop draft regulatory and implementing technical standards to ensure uniform conditions of application with respect to the provisions regarding the operational functioning of colleges of supervisors; and issue guidelines and recommendations.

- Practical arrangements are necessary for the effective functioning of colleges supervising global financial groups that sometimes involve more than a hundred national representatives. In practice, it might make sense to have more frequent meetings of core colleges, with less frequent meetings of the full college. Another challenge will be to organise interactions of "European" colleges with "global" colleges and to avoid two separate colleges for one bank. To service this system properly, the EBA will require very substantial resources to participate in college discussions in a meaningful way.

Supervisory mistakes can result in large fiscal costs. Indeed, a more comprehensive reform of the supervisory architecture in Europe has proved extremely difficult, reflecting the principle that responsibility for financial stability should be aligned with fiscal authority (Goodhart, 2004; Goodhart and Schoenmaker, 2006). It is therefore very difficult to have strong European level supervisory authority in the absence of fiscal underpinning. This problem was reflected in the fiscal safeguard clauses that ensure that powers of the EBA could "not in any way impinge on the fiscal responsibilities of the member states". To make the EBA truly effective, fiscal safeguards should be limited to cases where the impact on national fiscal obligations is direct and significant. Problems with burden sharing are a key obstacle blocking agreement towards direct supervision of large cross-border banks by the EBA. Given these constraints, the powers of the EBA should evolve gradually and a review of the new supervisory arrangements is foreseen after at most three years to determine whether further steps towards more integration are needed and whether a single supervisor would be more fit for the purpose.

The mandates of national supervisors in Europe differ greatly, both in terms of their scope and enforcement powers. This complicates supervisory co-operation, particularly in situations of financial stress and reinforces risks of regulatory arbitrage:

- Supervisory authorities in some countries should be institutionally strengthened. Both European and national institutions must have clear mandates and sufficient independence to undertake politically unpopular decisions (Rochet, 2008). In particular, sectoral competitiveness objectives and government policy goals (such as housing policies) should not prejudice decision-making at national level.

- The EBA will periodically organise and conduct peer reviews of some or all of the activities of competent authorities to further strengthen consistency in supervisory outcomes, ensuring uniform procedures and consistent approaches throughout the EU. To that end, the EBA shall develop methods to allow for objective assessment and comparison between the authorities reviewed.

- The EBA will play an active role in building a common European integrated supervisory culture Peer reviews will examine the adequacy of resources and governance arrangements of the competent 
It is important to establish the high level of credibility for the EBA. Experience of umbrella supervisory institutions in other OECD countries is rather disappointing. For example, the Federal Financial Institutions Examination Council (FFIEC) in the United States failed to establish a sufficiently strong position vis-à-vis the various supervisory authorities. As national supervisors in Europe are large institutions with long histories, they may be hesitant to give up power to European authorities. The resources of the EBA need to be adequate to ensure harmonisation, effective peer review process and dispute resolution. Current proposals foresee a relatively small number of staff (40 in the first year of operations to be increased to 90 by 2014). Although the EBA will not be undertaking direct supervision, the number of staff is nevertheless very small compared to the number of bank supervisors working in national authorities (Figure 14). The adequacy of this allocation of resources will periodically be reviewed by the European Commission.

Figure 14. Bank supervisory staff of national authorities 2007, full-time equivalent ${ }^{1}$

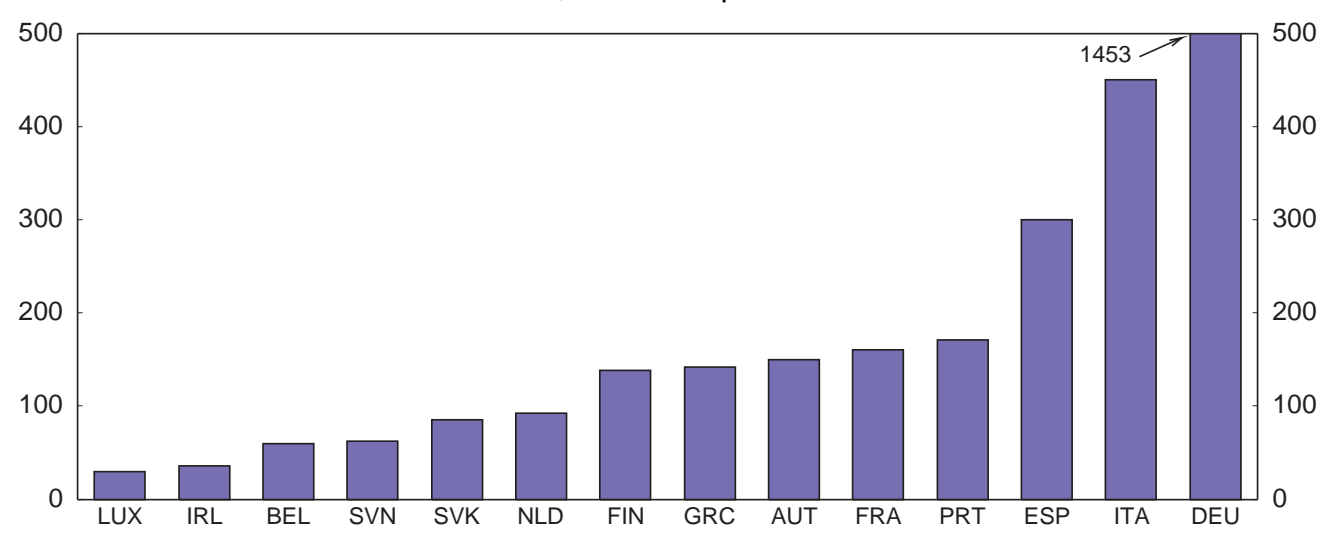

1. OECD estimate for Austria.

Source: World Bank, Bank Regulation and Supervision 2007 Database.

Ineffective information sharing often reflects weak mutual confidence linked to conflicting interests. In particular, sharing information about problems in one jurisdiction might lead to immediate ring-fencing in other jurisdictions. As a result, national supervisors in the build-up to and during the first stages of the financial crisis were not prepared to openly discuss vulnerabilities of their financial sectors. However, there are several other obstacles to optimal information sharing:

- Some national legal systems make open cross-border supervisory discussion difficult due to commercial and banking confidentiality laws. These laws need to be systemically reviewed and appropriately modified.

- Information sharing is complicated by lack of harmonisation in key supervisory definitions at the EU level, such as non-performing loans. Harmonisation would allow a meaningful cross-border dialogue, data tabulation, benchmarking, aggregation and European systemic risk analysis. This would also reduce reporting costs. Such harmonisation is underway under the auspices of the Commission.

- Supervisory architecture is very complex, and multiple reporting lines among home and host supervisors lead to possible information gaps and double information burdens. The EBA is now required to centralise the information received from competent authorities about institutions active in 
more than one country, and to share that information with the other competent authorities concerned. Building an EU-wide banking supervisory database would provide quasi-automatic access to supervisory information across borders. Eventually, banks could provide information directly to this database.

- Sharing qualitative information is difficult without intense and frequent operational contacts. The role of the EBA to take the lead in strengthening the functioning of colleges of supervisors is essential in this respect.

Removal of information barriers is not only crucial for improved cross-border supervision, but it is also likely to improve the quality of supervision more generally. For example, several nationally dominant banks have no peers within their country, but comparison to similar institutions abroad is often infeasible in the absence of effective information exchange. It is essential that newly created European bodies have full access to all national supervisory information.

There is a strong case for strengthening market discipline through supervisory transparency and disclosure (i.e. Pillar 3 of Basel). Improved disclosure was an important element of the institutional response to the banking crisis in Japan in the 1990s and European countries continue to lag behind the global trend. One obstacle is the lack of harmonisation of confidentiality laws in Europe. More fundamentally, there is resistance from national authorities to putting domestic institutions at a competitive disadvantage. The EBA will have to overcome this co-ordination problem. The EBA should review the confidentiality levels across countries and propose uniform disclosure pattern across countries that would be consistent with the emerging single rule book.

\section{An integrated crisis-management framework would reduce moral hazard}

The experience of the crisis in the euro area has shown that creditors, including holders of unsecured debt, have been protected from losses by public intervention. Although the value of shares has fallen considerably, equity investments have only rarely had their shareholdings diluted. This has added to the fiscal costs of resolution, aggravating budgetary problems and implying a substantial transfer of wealth. It is also likely to have signalled to financial institutions that bailouts may be available in future crises. Eliminating this moral hazard requires a framework for orderly and swift resolution that makes it possible for banks to fail without destabilising the financial system. The existence of such framework would have a first order impact on the behaviour of banks through the reduction of moral hazard problems: shareholders and creditors should not expect public intervention to relieve them from facing the full burden of a bank failure.

While crisis management and resolution is already difficult at the national level (for example, Northern Rock, IKB or Hypo Real Estate), it is particularly problematic in the context of systemically important cross-border institutions. During a crisis, quick but effective decisions are required. Actions need to be legally robust but should not require time-consuming judicial intervention. The relevant authorities need adequate powers and the ability to act, and a clear line of command is important. Yet, several problems of cross-border supervision are magnified in situations of financial stress, sometimes leading to the collapse of effective co-operation. It is therefore important that the European supervisory architecture is complemented with integrated crisis-management and -resolution framework, able to deal with failure of large and complex cross-border institutions.

Crisis management in the European Union still remains largely a national responsibility, mirroring the lines of fiscal responsibility. However, it has been increasingly supported by cross-border arrangements for co-ordination and information exchange. The CRD gives the consolidating supervisor responsibility for planning and co-ordinating supervisory actions in emergency situations, and requires the lead supervisor to 
alert all supervisors and central banks concerned as soon as is practicable when an emergency arises that could jeopardise the stability of the financial system in any EU country. The co-operation among EU authorities in the area of crisis management has been enhanced through the guidelines of the Committee of European Banking Supervisors and voluntary agreements in the form of non-binding memorandums of understandings (MoUs) between various authorities. Such agreements, which set out procedures for cooperation and information sharing in potential crisis situations, have been adopted at the regional and bilateral levels with respect to individual institutions. In addition, a series of multilateral MoUs set out the general framework for crisis management, bringing together all the relevant supervisory parties in 2003, 2005 and 2008.

The existing crisis-management framework needs to be strengthened to deal with the challenges of the cross-border bank crisis and to secure the desired supervisory co-operation. Although the worst-case outcome of a disorderly failure of systemically important institutions has been avoided, fiscal costs proved very substantial. Examples of difficulties in managing the crisis (Fortis, Icelandic banks) also showed that close cross-border co-operation is helpful but may not always be sufficient, and ex ante burden-sharing agreements would have helped. Response to the crisis was often ad hoc, marked by supervisory retrenchment to national jurisdictions and setbacks to single financial markets (Box 7). In several cases, the home authorities intervened alone, shouldering very large fiscal costs, while redeployment towards the home market has been often implicitly or explicitly expected (Fonteyne et al., 2010).

\section{Box 7. Major financial firms live globally but die locally: the case of Fortis}

Fortis was a major cross-border European financial group with total group assets of around EUR 800 billion before the crisis. Originating from the merger of Belgian and Dutch insurance companies, the group purchased BGL bank in Luxembourg. Following Fortis' takeover of parts of ABN Amro in 2007, it sought to raise more capital. Doubts emerged about its solvency during 2008 as the international banking crisis unfolded and investors began rapidly to lose confidence in its viability.

Even a long tradition of co-operation of financial regulators and considerable harmonisation of legal frameworks in the Benelux countries did not prevent a complicated, protracted and inflammatory resolution process along national lines (Lipsky, 2010). The initial agreement to save a group as a whole collapsed as it proved to be inadequate to stop the liquidity outflow of the bank, while finding an acceptable burden-sharing agreement was difficult. Fortis' Dutch operations were eventually taken over by the Netherlands government. The Belgian government provided extensive liquidity support to the remaining entity, of which $75 \%$ was sold to BNP Paribas and the rest held by the Belgian state. Luxembourg now holds one-third of the capital of BGL with the rest owned by BNP Paribas. This outcome was probably more costly than a joint solution for the group; it constituted a setback for financial integration in the Benelux countries and left bitter feelings among national supervisors (Fonteyne et al., 2010).

The Memorandum of Understanding, signed by the supervisory authorities, finance ministries and central banks in June 2008, reflected the increasing recognition of the weaknesses of the existing framework (Eisenbeis and Kaufman, 2006). It contains common principles on crisis management including on the conditions for the use of public funds and on the subsequent possible burden sharing, a common analytical framework and practical guidelines for crisis management. Cross-Border Stability Groups (CBSGs) are foreseen for all large cross-border financial groups and they should be provided with common tools to enable effective co-ordination between the national authorities involved in a crisis. These tools include operational criteria and ex ante principles for ex post burden sharing. Recovery and Resolution Plans for supervised institutions are to be elaborated and regular crisis-management simulation exercises conducted. However, at the time of agreement, the idea to agree on detailed ex ante burden-sharing agreements has been rejected, due to fears of moral hazard, insufficient flexibility and impingement of national sovereignty. 


\section{Box 8. The Nordic-Baltic Cross-Border Stability Group (NBCBSG)}

The co-operation agreement on cross-border stability, crisis management and crisis resolution signed on 17 August 2010 by finance ministers, central banks and financial supervisory authorities in the Nordic and Baltic countries, ${ }^{*}$ established the first European cross-border stability group. It is likely to set the standard for others, as it is based on a good record of close supervisory co-operation and density of systemically important institutions in Nordic countries. The objective of this agreement is to ensure that countries not only co-operate effectively to prevent financial crises, but are prepared to deal with crisis situations. By agreeing in advance on procedures for co-operation, sharing of information, assessments and resolution, the agreement aims to reduce financial crisis costs to a minimum and, when relevant and possible, to share them in a balanced and equitable manner. The main tasks of the NBCBSG include:

- Keeping up-to-date the necessary databases for financial and other relevant information regarding the financial groups.

- Identifying perceived legal and other possible obstacles to co-ordinated decision-making and joint solutions and encouraging authorities to work on their removals.

- Considering, to the extent agreed, alternative workable joint crisis-management tools and crisis-resolution mechanisms.

- $\quad$ Adopting the suggested information-sharing templates and assessment procedures.

- Initiating and evaluating stress tests and crisis simulations.

- Developing and updating criteria and models for possible sharing of net budgetary resolution costs.

The agreement outlines the initial algorithm for burden sharing that is based on:

- The relative importance of the financial group (either parent, subsidiary or branch) in the countries as measured by asset shares (summing to $100 \%$ ).

- The supervisory responsibilities for the same institution in the same countries (either $100 \%$ for home country status with full and exclusive power to act and influence, or $100 \%$ divided discretionarily among supervisory college members).

- $\quad$ Complementing factors, including systemic importance in a given country; the share of problem assets; quality of superior crisis prevention and early warning; and exceptionally high fiscal burden.

The agreement is not legally binding and recognises that the responsibility for the management and resolution of financial crises remains with the individual authorities, and that co-operation would remain fully voluntary. The agreement does not limit ring-fencing, where it is a legal obligation, as for example in Denmark, and is not based on a common bankruptcy framework. The benefits of the facility are therefore concentrated in early warning and early intervention phases, constituting a sort of prompt-corrective action approach.

* Denmark, Estonia, Finland, Iceland, Latvia, Lithuania, Norway and Sweden.

1. The establishment of the European System of Financial Supervision has been an important step towards more effective cross-border crisis management. The power to determine the existence of an emergency situation is now conferred on the Council, following a request by the European Commission, any of the European Supervisory Authorities, or the ESRB. In the emergency situation, the EBA will actively facilitate and, where deemed necessary, co-ordinate any actions undertaken by the relevant national competent supervisory authorities, and ensuring smooth exchange of information. It will be empowered to require national supervisory authorities to take specific actions to remedy an emergency situation. It may adopt an individual decision addressed to a financial institution requiring the necessary action to comply with its obligations under that legislation. The EBA may temporarily prohibit or restrict certain financial activities that threaten the orderly functioning and integrity of financial markets or the stability of the whole or part of the financial system. However, no decision adopted by the EBA may 
impinge in any way on the fiscal responsibilities of countries, weakening its effectiveness in the emergency situation.

2. To strengthen the EU crisis-management framework, the European Commission published a Communication in October 2010, leading to new legislation on crisis prevention, management and resolution (European Commission, 2010). The framework should include early intervention, crisis resolution and insolvency, and provide a harmonised toolbox of instruments in each phase supported by necessary legal changes and decision-making patterns. The roles and powers of national authorities, colleges and cross-border stability groups, the EBA and the ESRB should be outlined in detail, and triggers for intervention and of burden-sharing agreements defined:

- In the early intervention phase triggered by breach or likely breach of prudential requirements, the supervisory authorities should take measures with the main objective of restoring the stability and financial soundness of an institution when problems are developing. Corresponding changes in national legislation are necessary so that national authorities have similar powers to require, for instance, the raising of private capital, restructuring activities or ceasing certain practices, or, if these measures prove inadequate, to initiate the resolution process.

- A crisis resolution involves actions limiting the impact of bank failure on the rest of the financial system. It can lead either to a return to financial health after deep restructuring or to a wind-up and liquidation. This requires that authorities in different countries have wide-ranging but harmonised powers to take decisions, including selling assets and transferring liabilities; setting up good and bad banks; imposing haircuts on unsecured creditors; forcing debt to equity conversion; and allocating losses to shareholders. They should have an authority to provide bridge financing, assume public ownership, recapitalise banks and conclude mergers and acquisitions.

- Possible changes in the insolvency framework would need to first focus on enhancing national insolvency frameworks, but also on eliminating main differences in national insolvency laws that may give rise to conflicts. These rules should allow asset transferability and harmonisation of the criteria under which insolvency proceedings are initiated. In the longer run, a special common insolvency framework for cross-border banks could be developed.

3. A fundamental problem in designing the crisis-management framework relates to burden sharing between taxpayers of different countries. Ex post decisions, which characterise the current arrangements in Europe, may lead to under-provisioning and delays for recapitalisation, because countries may have an incentive to understate their share of the problem so as to incur a smaller share of the costs (Freixas, 2003). This leaves typically the home country with the decision of whether to shoulder the costs on its own or to close the bank. On the one hand, ex ante decisions on burden sharing may accentuate moral hazard (OECD, 2009). They might also prove difficult to agree and enforce: even though the agreement on the Nordic-Baltic Cross-Border Stability Group reflects principles on burden sharing set out by the third EUwide MoU (Box 4.8), "its provisions may not give rise to any legal claim on behalf of any party or third parties in the course of their practical implementation". An effective crisis-management agreement is further complicated by ring-fencing: at the moment of a crisis, the authorities in several countries are obliged by law to protect domestic depositors and creditors, for example, by seizing local assets of the local branch of a foreign bank. Legal changes are therefore necessary so that principles of cross-border burden sharing are enshrined in law and interests of other countries are taken into account in the crisismanagement process. As this affects the fiscal responsibilities of the individual countries, such legal changes would have to be carefully designed.

4. Recovery and Resolution Plans (RRPs) or living wills are important instruments that may ensure that systemically important banks in distress can be either rapidly resolved or wound down without 
significant disruption to the financial system. RRPs should outline how a bank would react to a whole range of possible stresses, including contingency funding plans and sales of assets and business lines, making it simpler and less costly for authorities to resolve a bank by creating "a permanent state of readiness" (Bailey, 2009). To keep RRPs effective, national supervisors and the EBA will have to jointly recognise main impediments to cross-border resolution, and to ensure that RRPs remain accurate, adequate and updated through on-going stress tests and crisis-management simulation exercises. Finally, to be effective in the cross-border context, resolution plans may need to be supported by binding burden-sharing agreements and possibly by other resolution procedures enshrined in national legislation.

5. Currently legislative proposals to fully harmonise deposit guarantee schemes (DSG) are being discussed. Prior to the crisis, there was significant variation in the design of deposit guarantee schemes across countries, as the harmonisation was limited to the minimum coverage level. Although European countries agreed during the crisis to gradually raise the ceilings of their insurance schemes to a common level of EUR 100000 by the end of 2010, variations in the types of deposits covered, the amount of coverage, risk-based premia and funding arrangements remained. It gave depositors incentives to engage in regulatory arbitrage. This happened among clients of UK banks. who transferred deposits to branches of Irish banks, which had been granted unlimited protection. The planned amendment of the DGS directive will significantly limit such differences by harmonising the coverage level and the scope of insured depositors and products. To make these regulatory changes effective, the European Banking Authority should now play an important role in peer reviewing and stress-testing national schemes, and helping to settle possible inconsistencies, to avoid uncertainty and cross-border spillovers from bank failures. The host country should also have the right to request confirmation that the home country has the financial capacity to effectively protect deposits of clients of branches to avoid the de facto transfer of liability towards the host country, as happened during the Icelandic banks crisis.

6. Funding mechanisms are an important issue which complements the crisis management system. While the final cost of resolution should be borne by private stakeholders, up-front and temporary funding by public authorities may be necessary to ensure that banks can be wound up while covering different costs and providing continuity of certain key services..All possibilities should be analysed, including prefunded resolution funds financed with risk-based levies, but also broadening the mandate of deposit guarantee schemes, which already exists in all countries, to provide for, among others, bridge financing, transferring of assets and liabilities and financing bank/bad asset splits. The solution should not bring benefits to shareholders, management and uninsured creditors to avoid moral hazard and distortions of competition. Harmonised operations of resolution funding should mirror increasing broader integration in supervisory arrangements and strong co-ordination in the actions of the national resolution authorities. Otherwise, introductions of resolution funding mechanisms can have some negative implications in terms of level playing field and contribute less than desired to a better cross-border crisis management. Yet, the first two quasi-resolution funds are being set up unilaterally.

7. Synchronisation in reforms leading to more internationally harmonised on-going microprudential supervision, macroprudential oversight and crisis-management framework is essential for ensuring stability and level playing field in the European banking system. Regular review of the new arrangements will determine whether further steps towards an integrated EU-wide framework for cross-border financial institutions might contribute to these goals. 


\section{Bibliography}

Acharya, V. V. and P. Schnabl (2010), "Do Global Banks Spread Global Imbalances? The Case of AssetBacked Commercial Paper During the Financial Crisis of 2007-2009”, IMF Economic Review, forthcoming.

Bailey, A. (2009), "Recovery and Resolution Plans", Remarks during Santander International Banking Conference, Madrid, 17 November.

Baker, D. and T. McArthur (2009), "The Value of the 'Too Big to Fail' Big Bank Subsidy", CEPR Issue Brief, September.

Barnes, S. (forthcoming), "Resolving and avoiding unsustainable imbalances", OECD Economics Department Working Papers, OECD, Paris.

Bayoumi, T. and O. Melander (2008), "Credit Matters: Empirical Evidence on U.S. Macro-Financial Linkages”, IMF Working Paper, No. 08/169.

BCBS (Basel Committee on Banking Supervision) (2010), "An Assessment of the Long-Term Economic Impact of Stronger Capital and Liquidity Requirements", Bank for International Settlements, August.

Blank, S. and C. M. Buch (2007), "International Bank Portfolios: Short- and Long-Run Responses to the Business Cycle", CGFS Papers chapters, in Bank for International Settlements (ed.), Research on Global Financial Stability: the Use of BIS International Financial Statistics, Vol. 29, pp. 128-155.

Blundell-Wignall, A., G. Wehinger and P. Slovik (2009), "The Elephant in the Room: The Need to Deal with What Banks Do", OECD Financial Market Trends, Issue 2, OECD, Paris.

Blundell-Wignall, A. and P. Atkinson (2010), “Thinking Beyond Basel III - Necessary Solutions for Capital and Liquidity”, OECD Financial Market Trends, Issue 1, OECD, Paris.

Borio, C. (2003), “Towards a Macroprudential Framework for Financial Supervision and Regulation?", ESifo Economic Studies, Vol. 49, No. 2/2003, pp. 181-216.

Borio, C. and I. Shim (2007), “What Can (Macro)-Prudential Policy Do to Support Monetary Policy?”, in Bank of Thailand (ed), Inflation Targeting in Emerging Market Countries, Proceedings of a conference, Bank of Thailand, 13-14 November 2006. Also available as BIS Working Papers, No. 242, December.

Cassola, N., C. Holthausen and M. Lo Duca (2010), “The 2007/2009 Turmoil: A Challenge for the Integration of the Euro Area Money Market", mimeo, ECB.

Catarineu-Rabell, E., P. Jackson and D. Tsomocos (2005), "Pro-Cyclicality and the new Basel Accord Banks' Choice of Loan Rating System”, Economic Theory, No. 26.

Cetorelli, N. and L. S. Goldberg (2010), "Global Banks and International Shock Transmission: Evidence from the Crisis", IMF Economic Review, forthcoming. 
CGFS (Committee on the Global Financial System) (2010), "Long-Term Issues in International Banking”, CGFS Papers, No. 41.

Claessens, S., R. J. Herring and D. Schoenmaker (2010), "A Safer World Financial System: Improving the Resolution of Systemic Institutions", Geneva Reports on the World Economy, 12.

Coeurdacier, N. and P. Martin (2007), "The Geography of Asset Trade and the Euro: Insiders and Outsiders", CEPR Discussion Papers, No. 6032.

De Blas, B. and K. Russ (2008), "FDI in the Banking Sector: Why Borrowing Costs Fall While Spread Proxies Increase", mimeo, Universidad Autonoma de Madrid and University of California at Davis.

De Bondt, G. et al. (2010), "The Euro Area Bank Lending Survey Matters: Empirical Evidence for Credit and Output Growth”, ECB Working Paper, No. 1160.

De Larosière Group (2009), "Report of the High-Level Group on Financial Supervision in the EU", European Commission, Brussels.

ECB (2007), Review of the International Role of the Euro.

ECB (2009a), EU Banks’ Funding Structures and Policies.

ECB (2009b), Euro Money Market Survey.

ECB (2009c), Financial Stability Review, December.

ECB (2010a), Structural Indicators for the EU Banking Sector.

ECB (2010b), Financial Integration in Europe, April.

ECB (2010c), Financial Stability Review, June.

Eisenbeis, R. A. and G. G. Kaufman (2006), "Bank Crisis Resolution and Foreign-Owned Banks”, Federal Reserve Bank of Atlanta Economic Review, Fourth Quarter, pp. 1-18.

European Commission (2010), "An EU Framework for Crisis Management in the Financial Sector", Commission Communication, COM (2010) 579 final, 20 October.

Fernandez de Lis, S. and A. G. Herrero (2008), "The Housing Boom and Bust in Spain: Impact of the Securitisation Model and Dynamic Provisioning”, BBVA Working Paper.

Fernandez de Lis, S. and A. G. Herrero (2010), "Dynamic Provisioning: Some Lessons from Existing Experiences", ADBI Working Paper Series, May 2.

Fonteyne, W. et al. (2010), "Crisis Management and Resolution for a European Banking System”, IMF Working Paper, WP/1070.

Freixas, X. (2003), "Crisis Management in Europe”, in J. Kremers, D. Schoenmaker and P. Wierts (eds.), Financial Supervision in Europe, Cheltenham: Edward Elgar, pp. 102-119.

Goldberg, L. (2007), "Financial Sector FDI and Host Countries: New and Old Lessons", Economic Policy Review, Federal Reserve Bank of New York, pp. 1-17. 
Goodhart, C. (2004), “Some New Directions for Financial Stability”, Per Jacobsson Lecture, Bank for International Settlements, Basle.

Goodhart, C. and D. Schoenmaker (2006), "Burden Sharing in a Banking Crisis in Europe", Penning- Och Valutapolitik, 2/2006, pp. 34-57.

Hempell, H.S. and C. Kok Sørensen (2009), "The Impact of Supply Constraints on Bank Lending in the Euro Area .Crisis Induced Crunching?", paper presented at the ECB Workshop on "Challenges to monetary policy implementation beyond the financial market turbulence" (30 Nov.-1 Dec. 2009, Frankfurt).

Hoeller, P. and D. Rae (2007), "Housing Markets and Adjustment in Monetary Union", OECD Economics Department Working Papers, No. 550, OECD, Paris.

IMF (2010), "Euro Area Policies: 2010 Article IV Consultation - Staff Report"; Staff Supplement; Public Information Notice on the Executive Board Discussion; and Statement by the Executive Director for Member Countries, Country Report No. 10/221.

Jokipii, T. and A. Milne (2006), "The Cyclical Behaviour of European Bank Capital Buffers", Discussion Paper, Bank of Finland, No. 17/2006.

Kager, M. (2006) “The Perspective of a Practicing Banker". in Financial Supervision in Europe: Comments by ELEC members, Cahier Comte Boël, No. 12, E.L.E.C., Brussels, pp. 21-24, January.

Kalemli-Ozcan, S., E. Papaioannou and J.-L. Peydro (2010), "What Lies Beneath the Euro's Effect on Financial Integration? Currency Risk, Legal Harmonisation or Trade", Journal of International Economics, Elsevier, Vol. 81(1), pp. 75-88, May.

Kashyap, A. N. and J. Stein (2004), "Cyclical Implications of Basel II Capital Standards", Economic Perspectives, Federal Reserve Bank of Chicago, Vol. 28, pp. 18-31.

Lane, P. R. and G. M. Milesi-Ferretti (2010), “The Cross-Country Incidence of the Global Crisis”, IMF Economic Review, forthcoming.

Lanoo, K. (2010), "Europe 2020 and Financial Crisis", CEPS Commentary, Centre for European Policy Studies.

Lipsky, J. (2010), “Towards an International Framework for Cross-Border Resolution”, Remarks delivered at the ECB and its Watchers Conference XII Frankfurt, Germany, July 9.

Lowe, P (2002), “Credit Risk Measurement and Pro-Cyclicality”, BIS Working Papers, No. 116, September.

Maddaloni, A. and J.-L. Peydro (2010), "Bank Risk-Taking, Securitization, Supervision, and Low Interest Rates: Evidence from Lending Standards”, Review of Financial Studies, forthcoming.

McGuire, P. and P. Wooldridge (2005), “The BIS Consolidated Banking Statistics: Structure, Uses and Recent Enhancements", BIS Quarterly Review, September.

Milesi-Ferretti, G. M. and C. Tille (2010), "The Great Retrenchment: International Capital Flows during the Global Financial Crisis", Economic Policy, forthcoming. 
Navaretti, G. et al. (2010), "Multinational Banking in Europe: Financial Stability and Regulatory Implications. Lessons from the Financial Crisis", Centro Studi Luca Development Studies Working Papers, No. 292.

OECD (2009), OECD Economic Surveys: Euro Area, Vol. 2009/1, January, OECD, Paris.

OECD (2010), "Counter-Cyclical Economic Policy”, in: OECD Economic Outlook. No. 87, May, OECD, Paris.

Penetta, F. et al. (2009), "Financial Sector Pro-cyclicality. Lessons from the Crisis", Bank of Italy Occassional Papers, No. 44.

Persaud, A. (2008), “The Inappropriateness of Financial Regulation”, VOX EU webpage, 1 May.

Portes, R. (2009), “Global Imbalances”, in M. Dewatripont, X. Freixas, and R. Portes (ed.), Macroeconomic Stability and Financial Regulation: Key Issues for the G20, Centre for Economic Policy Research, London.

Rochet, J.-C. (2008), "Comments on the Article by A. Kashyap, R. Rajan and J. Stein 'Rethinking Capital Regulation", Federal Reserve of Kansas City Symposium on Maintaining Stability in a Changing Financial System, Jackson Hole, Wyoming, 21-23 August.

Spiegel, M. (2009), "Monetary and Financial Integration in the EMU: Push or Pull?", Review of International Economics, , 17(4), pp. 751-776.

Wehinger, G. (2008), "Lessons from the Financial Market Turmoil: Challenges Ahead for the Financial Industry and Policy Makers", OECD Financial Market Trends, OECD, Paris. 


\section{WORKING PAPERS}

The full series of Economics Department Working Papers can be consulted at www.oecd.org/eco/workingpapers/

827 Resolving and avoiding unsustainable imbalances (December 2010) by Sebastian Barnes

826 Current account imbalances in the euro area: a comparative perspective (December 2010) by Sebastian Barnes, Jeremy Lawson and Artur Radziwill

825. Does fiscal decentralisation strengthen social capital? Cross-country evidence and the experiences of Brazil and Indonesia

(December 2010) by Luiz de Mello

824. Fiscal decentralisation and public investment: The experience of Latin America (December 2010) by Luiz de Mello

823. Product market regulation and competition in China (December 2010) by Paul Conway, Richard Herd, Thomas Chalaux, Ping He and Jianxun Yu

822. Reforming China's monetary policy framework to meet domestic objectives (December 2010) by Paul Conway, Richard Herd and Thomas Chalaux

821. Regulatory reforms to unlock long-term growth in Turkey

(December 2010) by Rauf Gönenç and Lukasz Rawdanowicz

820. After the crisis: mitigating risks of macroeconomic instability in Turkey (December 2010) by Łukasz Rawdanowicz

819. The 2008-09 crisis in Turkey: performance, policy responses and challenges for sustaining the recovery

(December 2010) by Łukasz Rawdanowicz

818. Fiscal-consolidation strategies for Canadian governments

(November 2010) by Yvan Guillemette

817. The land transport sector: policy and performance

(November 2010) by Jan Persson and Daeho Song

816. A simple model of the relationship between productivity, saving and the current account (November 2010) by Jean-Marc Fournier, Isabell Koske

815. The impact of structural policies on saving, investment and current accounts (November 2010) by Clovis Kerdrain, Isabell Koske, Isabelle Wanner

814. Towards a less distortive and more efficient tax system in Portugal (November 2010) by Alvaro Pina 
813. Are global imbalances sustainable? Shedding further light on the causes of current account reversals

(November 2010) by Luiz de Mello, Pier Carlo Padoan, Linda Rousová

812. Turkey's improving integration with the global capital market: Impacts on risk premia and capital costs

(November 2010) by Rauf Gönenç, Saygin Şahinöz, Özge Tuncel

811. Trade linkages in the OECD trade system

(October 2010) by Jérôme Brézillon, Stéphanie Guichard and Dave Turner

810. Enhancing the effectiveness of social policies in Indonesia

(October 2010) by Margherita Comola and Luiz de Mello

809. Tackling the infrastructure challenge in Indonesia

(October 2010) by Mauro Pisu

808. Phasing out energy subsidies in Indonesia

(October 2010) by Annabelle Mourougane

807. Implementing cost-effective policies in the United States to mitigate climate change (October 2010) by David Carey

806. Restoring fiscal sustainability in the United States

(October 2010) by Patrick Lenain, Bob Hagemann and David Carey

805. Norway: Sustainable development: climate change and fisheries policies (September 2010) by Paul O’Brien

804. Netherlands: How the transport system can contribute to better economic and environmental outcomes

(September 2010) by Tomasz Koźluk

803. Public-private partnerships and investment in infrastructure

(September 2010) by Sónia Araújo and Douglas Sutherland

802. Sustaining the momentum of fiscal reform

(September 2010) by Colin Forthun and Robert Hagemann

801. The consequences of banking crises for public debt

(September 2010) by Davide Furceri and Aleksandra Zdzienicka

800. A simulation model of federal, provincial and territorial government accounts for the analysis of fiscal-consolidation strategies in Canada

(September 2010) by Yvan Guillemette

799. Product market regulation: extending the analysis beyond OECD countries

(October 2010) by Anita Wölfl, Isabelle Wanner, Oliver Röhn, Giuseppe Nicoletti

798. Korea's green growth strategy: mitigating climate change and developing new growth engines (July 2010) by Randall S. Jones and Byungseo Yoo 